\title{
Article \\ Strategic Allocation of Development Projects in Post-Conflict Regions: A Gender Perspective for Colombia
}

\author{
Raphael J. Nawrotzki *(D), Verena Gantner, Jana Balzer (D), Thomas Wencker and Sabine Brüntrup-Seidemann $\mathbb{D}$
}

check for

updates

Citation: Nawrotzki, R.J.; Gantner, V.;

Balzer, J.; Wencker, T.;

Brüntrup-Seidemann, S. Strategic

Allocation of Development Projects

in Post-Conflict Regions: A Gender

Perspective for Colombia.

Sustainability 2022, 14, 2304. https://

doi.org/10.3390/su14042304

Academic Editors: Angela

Wroblewski, Beate Littig

and Astrid Segert

Received: 13 January 2022

Accepted: 11 February 2022

Published: 17 February 2022

Publisher's Note: MDPI stays neutral with regard to jurisdictional claims in published maps and institutional affiliations.

Copyright: () 2022 by the authors Licensee MDPI, Basel, Switzerland. This article is an open access article distributed under the terms and conditions of the Creative Commons Attribution (CC BY) license (https:/ / creativecommons.org/licenses/by/ $4.0 /)$.
German Institute for Development Evaluation (DEval), 53113 Bonn, Germany; verena.gantner@deval.org (V.G.); balzer.jana@googlemail.com (J.B.); thomas.wencker@deval.org (T.W.); seideman@web.de (S.B.-S.)

* Correspondence: r.nawrotzki@gmail.com; Tel.: +49-1577-6387218

\begin{abstract}
We know little about the general geographic allocation of development projects in postconflict regions, and specifically of gender-focused projects. In this study, we explore whether donor agencies prefer to work in "safe" places or dare to operate in conflict-affected zones. Using Colombia as a case study, we combine data on battle deaths from the UCDP Georeferenced Event Dataset (1994-2004) with georeferenced information on the location of development projects from the Colombia AIMS dataset (2006-2013) and manually geocode data for German-funded development projects (2012-2018) with gender as a significant objective. Using count models $(N=1120)$, we find a statistically strong and positive relationship: an increase in battle deaths increases the number of development projects (with and without gender-focus) in a municipality. Interaction models further reveal an amplification of this relationship for regions with a large proportion of female-headed households, as well as a high number of formally employed and literate women. A context-sensitive interpretation of our findings suggests that (1) development projects in general, and German-funded gender-focused projects in particular, dare to operate in post-conflict settings; (2) women may play an active role as community leaders and mobilizers to influence the allocation of development programs to certain regions.
\end{abstract}

Keywords: conflict; post-conflict; gender; development cooperation; Colombia; geocoding

\section{Introduction}

The number of developing countries affected by conflicts is on the rise [1]. At the same time, the amount of official development assistance (ODA) to fragile and conflictaffected countries has increased, mainly in the form of humanitarian assistance [2]. As an example, in 2017, German Development Cooperation (GDC) spent more than 60\% of all bilateral ODA on conflict-affected states [3]. A growing literature examines the relationship between development cooperation and conflict. Most of these investigations operate at the country level [4-10]. Recently, given the emergence of highly granular data on project locations of development cooperation, a growing number of studies consider sub-national variations when investigating this relationship [11]. So far, there is no clear consensus on the relationship. While several studies find that development cooperation can increase conflict [12-16], this is not confirmed by other studies [17,18], or is only evident for certain sectors [19] or types of intervention [20]. Of particular interest in terms of the present study is the spatial allocation of development projects in post-conflict settings. Because little is published on project allocation in post-conflict settings, the following paragraphs discuss determinants in general.

Development actors usually decide in which country to operate, based on their political strategies, but also based on the economic needs and administrative performance of the recipient nations [21]. Several theoretical models help to explain the allocation decision. First, the recipient need model [22] suggests that donors may feel morally obligated to assist countries that experience high levels of disturbance, including violent conflicts, and 
are therefore in need of support $[21,23,24]$. Based on this model, we would assume that development agencies favor working in conflict-ridden countries. Yet, donor agencies do not always act according to altruistic motives. Support for post-conflict recovery may have the goal of securing future cooperation [23] or of honoring and protecting political and economic ties [22,25]. In contrast, the recipient merit model suggests that donor agencies prefer to work in politically stable nations with good governance structures in place [26-28]. Based on this model, we would assume that donor agencies shy away from conflict countries and prefer to work in safe locations.

Considerably fewer studies investigate sub-national factors that determine the allocation of projects within conflict-affected countries [29]. Donor agencies and the recipient government usually jointly decide the location of new projects. Recipient governments may seek to direct aid flows to political allies [30] and the seat of powerful elites [29,31]. Yet, governments may also decide to invest in regions with strong political opposition in order to build trust among the population [32].

On the donor side, agencies may prefer to implement projects in safe areas (e.g., the capital) out of concern for the safety of their staff [33] (safety-first hypothesis). In contrast, aid flows in Angola, Mozambique, and Sierra Leone were directed to conflict-prone regions as an active strategy of conflict resolution and socio-economic rehabilitation [29] (needfirst hypothesis).

When deciding on where to implement a project, donor agencies also consider population characteristics [34]. Similar to allocation decisions at the national level, needs-based considerations play an important role at the local level, and projects are thought to gravitate towards poorer regions [35-37]. In general, donors might also allocate higher aid flows to countries with larger gender gaps in specific sectors [38,39]. Recent studies using geocoded data on project locations point out that aid is not always allocated to the poorest areas $[40,41]$. However, when singling out donors that focus their work on inequalities, especially gender inequality, there is evidence that they specifically target areas with a high proportion of vulnerable groups [42].

Because of growing concerns about corrupt governments and politically motivated favoritism in project allocation, donor agencies may increasingly collaborate with community groups [43]. The presence of strong community groups is therefore an important population factor that may encourage the placement of projects in certain regions. As an example, female activism in Colombia has blossomed unprecedentedly during the peace process $[44,45]$. In response, donor agencies collaborated with women's groups to assist in efforts to promote peace [44].

Against the backdrop of the various factors influencing the allocation of development projects, we explore whether development cooperation prefers to work in safe places (safety-first hypothesis) or actively targets conflict-affected areas (need-first hypothesis). We focus in this study on Colombia due to its long history of violent conflict and its unique gender dynamics in the post-conflict period.

In 1946, violent confrontations between the Liberal Party and the Conservative Party began in Colombia [46]. Over the years, new revolutionary groups were formed, among them the Revolutionary Armed Forces of Colombia (FARC), which opposed the Colombian government with heavy military force [46]. Although there was a decline in high-intensity conflict after 2004 [47], it was only in 2016 that the Colombian government reached a peace agreement with FARC, ending 52 years of armed conflict [48]. Violent conflicts were unevenly distributed across the country and concentrated in several areas [49]. The armed conflict has caused the forced displacement of more than 6.9 million Colombians [50], the second-largest population of internally displaced persons (IDPs) in the world after Syria [51]. Given our interest in local allocation patterns in post-conflict settings, our first research question asks:

RQ1: Are international development programs located in regions that have historically experienced conflict in Colombia? 
Although women are less likely to actively participate in armed conflict, they frequently suffer from the indirect effects of conflict, such as with poorer health care [52]. In Colombia, about half of the more than nine million victims of the armed conflict were women [53]. Among the survivors of the conflict, many women and girls experienced sexual violence [54-56]. In Colombia, girls and women continue to be the most vulnerable, and are at the greatest risk of experiencing domestic violence [56,57]. Violence against women and girls emerges in the context of strong traditional gender roles within Colombian society [45]. Additionally, other characteristics such as religion, ethnicity, and sexual orientation can cause intersecting experiences of discrimination, notably by indigenous and Afro-Colombian displaced women [54,58,59].

The international community is aware of the gender dimensions of conflict. In the year 2000, the UN Security Council resolution 1325 [60] on "Women, Peace and Security" was unanimously adopted and currently forms a normative frame for sustainable development work in post-conflict contexts [47]. The resolution calls for comprehensive measures to be taken against sexualized and gender-based violence in conflicts. Moreover, it stresses the importance of women's equal participation and full involvement in all efforts for the promotion and maintenance of peace and security [61].

The Sustainable Development Goals (SDGs), which set the standards for sustainable global development, emphasize the importance of promoting gender equality (SDG 5) and the development of peaceful and inclusive societies (SDG 16) [62]. SDG 5 seeks to ensure that women and girls everywhere have equal rights and opportunities and are able to live free of violence and discrimination. SDG 16 aims to promote peaceful and inclusive societies that provide access to justice for all and to build effective, accountable and inclusive institutions at all levels. In many respects, the achievement of both goals is only conceivable in a linked way, because conflicts have gender dimensions. As such, this research is based on the notion that development projects in post-conflict regions will only be sustainable if they pay special attention to gender aspects.

Conflicts can empower or disempower women through changes in socio-cultural structures [63]. Changes in social rules and norms following a conflict provide donors with a window of opportunity to contribute to gender equality [47]. Gender inequalities are still evident in various parts of today's public life in Colombia. For example, women remain under-represented in parliament [64] and in the formal labor market and receive less income than their male counterparts [65].

Germany has committed to implementing UN Security Council resolution 1325 and has anchored the "Women, Peace and Security Agenda" in various guidelines and action plans to better reach SDG 5 by the end of 2030 [62]. With the promotion of gender equality as a central goal of German development cooperation and a guiding principle of action [66], it comes as no surprise that the majority of bilateral German development cooperation projects in Colombia between 2012 and 2018 state gender as a "significant" program objective. Given the importance of a gender perspective for post-conflict settings, our next two research questions ask:

RQ2: Are development projects with gender as a significant objective located in regions that have historically experienced conflict in Colombia?

RQ3: Can gender characteristics of the population explain the relationship between conflicts and the geographic allocation of development programs?

\section{Materials and Methods}

In this study, we explore the relationship between gender and placement of development projects in post-conflict regions across donors, and subsequently focus on German projects. The focus on German projects is based on theoretical and practical considerations. First, Germany is one of the primary donors to Colombia [67], with peacebuilding and conflict prevention as the most important focus alongside environmental policy and resource conservation and sustainable economic development. Germany's development cooperation with Colombia focuses on regions particularly affected by conflict [68]. More impor- 
tantly, for this study, compared to all other bilateral donors, Germany allocated the largest amount of funds for programs that target gender as a significant objective [67]. Second, as part of a larger evaluation of German development cooperation on supporting gender equality in post-conflict contexts [47], we were able to obtain detailed project information from the various implementing organizations which enabled us to manually geocode project location.

We obtained the geographic location of international development programs across donors from the Colombia Aid Information Management System (AIMS) geocoded data set (v. 1.1.1), prepared by AidData [29,69]. The Colombia AIMS data contains information on sectors and donors, but the georeferenced information focuses heavily on programs funded by the United States and includes only a few programs funded by the German government [70]. In the absence of a comprehensive dataset on German development aid, we manually georeferenced locations for German-funded projects, owing to the particular importance of this donor.

To identify conflict locations, we used the UCDP (Uppsala Conflict Data Program) Georeferenced Event Dataset (version 19.1) that contains the location of battle deaths for the period 1989-2018 [71,72]. The units of analysis for this study are municipalities $(\mathrm{N}=1120)$, and we derived administrative boundary shapefiles from the Colombian National Administrative Department of Statistics (DANE).

To construct various socio-demographic variables, including various gender variables, we employed microdata ( $10 \%$ extract) from the 2005 Colombian census, the most recent census data publicly available. Census data was collected by DANE and harmonized and made available through IPUMS-International [73]. The census data contain information on the municipality of residence, which permits integration with other spatial data. Data on administrative capacity was collected by the Colombian National Planning Department (DNP) [74]. Various geospatial control variables were obtained from the GeoQuery platform, hosted by AidData, which allows aggregating raster data to the second administrative level [75]. Finally, raster data of night-time lights was obtained from the Visible Infrared Imaging Radiometer Suite (VIIRS) Day/Night Band (DNB), made publicly available by the US National Oceanic and Atmospheric Administration (NOAA) [76].

In this study, we explored whether development projects are strategically located in Colombian municipalities that have historically experienced conflicts. We employed locations of development programs from the Colombia Aid Information Management System (AIMS), geocoded and provided by AidData [69]. We selected projects with precision classes 1 to 3 to ensure that GPS coordinates were precise enough to be located in municipalities. Projects with the required precision started implementation during the years 2006-2013. For each municipality, we then counted the number of unique projects. The AIMS dataset contains, for each project, information on the respective sector. This allowed us to construct separate outcome variables for conflict prevention $(\mathrm{CP})$ projects (code: 152) and projects focused on women (W) (code: 420).

Given the importance of Germany as important donor for Colombia, we geocoded projects implemented by the German Gesellschaft für Internationale Zusammenarbeit (GIZ) and the Kreditanstalt für Wiederaufbau (KfW) during the period of 2012-2018. Geocoding was performed manually, based on project documents, following the methods implemented by AidData [77] in line with the IATI standards (DFID, 2018). As part of a larger evaluation "Supporting gender equality in post-conflict contexts" [47], project documents were made available through KfW and GIZ based on a special request supported by the German Federal Ministry of Economic Cooperation and Development (BMZ). From the available projects marked as "Peace and Security" and "Gender Equality" $(\mathrm{N}=35)$, we only geocoded projects for which a progress report or final report was available and implementation at the indicated location is assured. This resulted in a usable sample of $\mathrm{N}=17$ projects implemented across 74 locations. Using a Geographic Information System (GIS), we ultimately located projects within municipalities and generated our outcome variable of 
German-funded projects with gender as a significant objective (GG projects for short). We henceforward refer to this data as "DEval data". Figure 1 depicts unique project locations (red dots) and the number of projects implemented in each municipality (color shading) for our four outcome variables. Projects appear to cluster around large cities and in the northern regions.
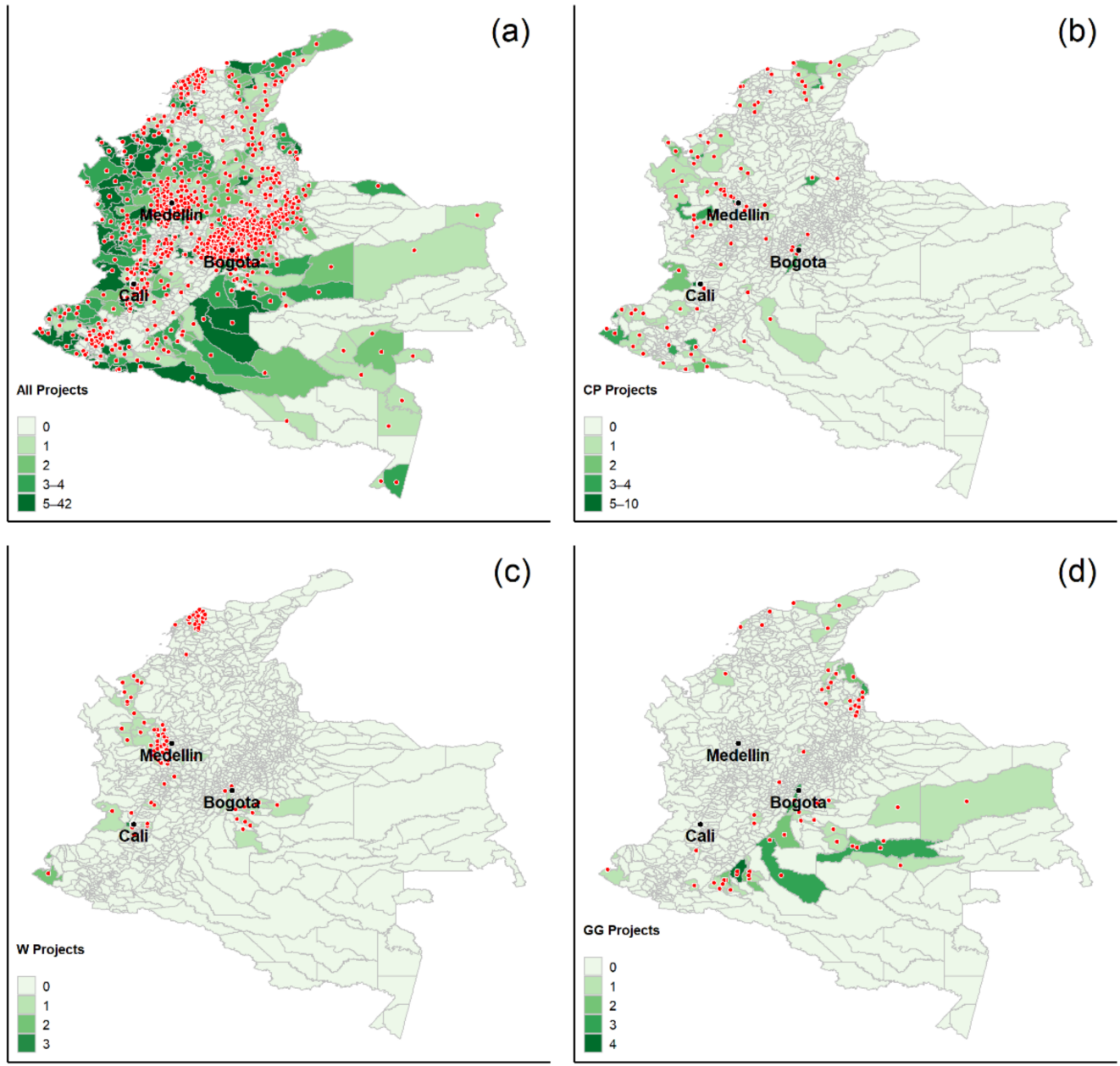

Figure 1. Project locations across Colombia. (a) All projects, (b) conflict prevention $(\mathrm{CP})$ projects, (c) projects focused on women (W), (d) German-funded projects with gender as significant objective (GG); red dots indicate project locations; green shading reflects the number of projects for each municipality; maps are oriented so that the top faces north.

We conceptually understand the presence of a conflict as a subnational indicator of state fragility [14,78]. Following Weber [79], a functional state has the monopoly of the legitimate use of violence within a territory. The use of physical violence by organized non-state actors thus challenges statehood and indicates fragility.

We employed data from the UCDP Georeferenced Event Dataset. The UCDP data contains point locations for events of organized violence including the number of battle deaths. We located conflicts within municipalities and computed the total count of battle deaths over the period 1994-2004 (see Figure 2). This period can be considered a time of high-intensity conflict in Colombia. After 2004, the number of battle deaths declined considerably, marking the beginning of the post-conflict period around 2006-2007 [47]. Large numbers of battle deaths were recorded, particularly in municipalities southeast of Bogota. 


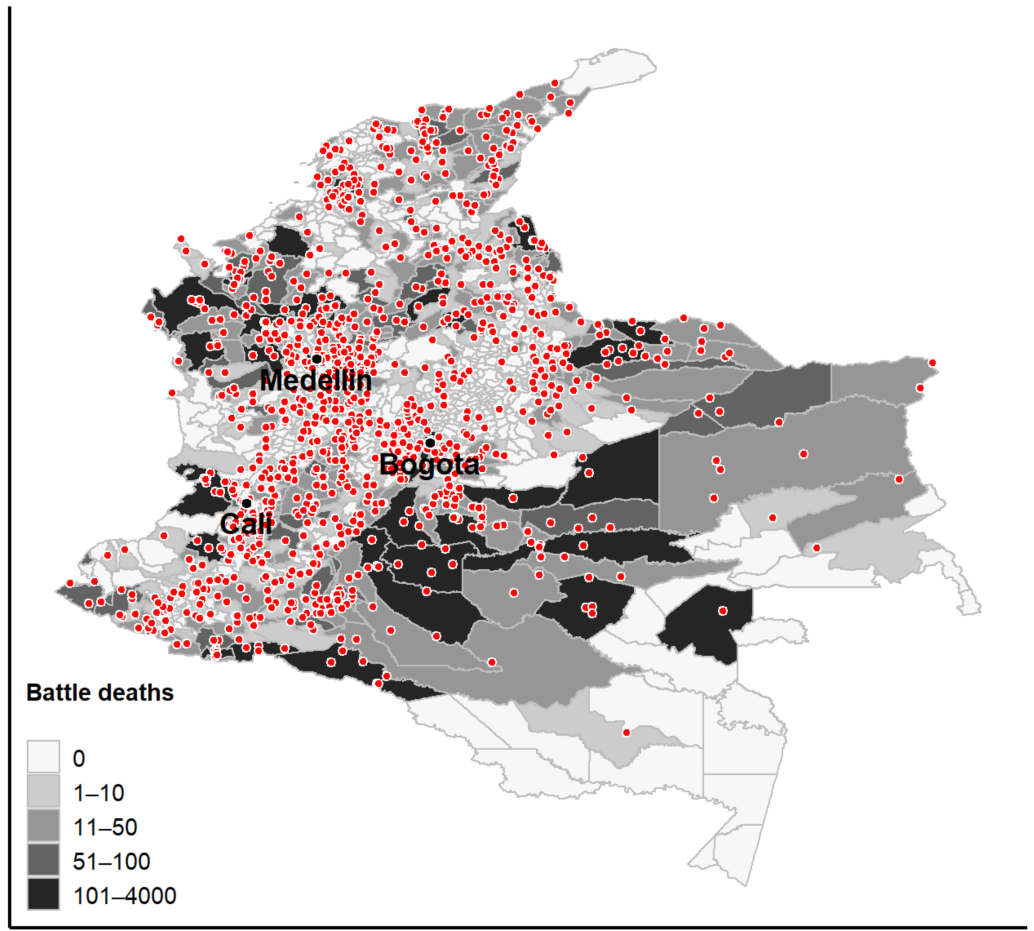

Figure 2. Battle deaths by municipalities across Colombia, 1994-2004. Red dots indicate battle death locations; shaded area reflects the number (sum) of battle deaths for each municipality across the period 1994-2004; map oriented so that top faces north.

Achieving gender equality has been an established goal of international donors in the last decades [80], which is in line with the commitments of the international community that were anchored in the Millennium Development Goals (MDG) [81,82]. Consequently, donors stepped up gender-mainstreaming efforts, and aid allocation to gender-sensitive programs has increased since 1999 [83]. The 2030 agenda for sustainable development further advanced the importance of gender equality, with Goal 5 dedicated to achieving gender equality and empowering all women and girls while highlighting that gender equality is a main priority that should be realized across all other SDGs [62].

Donors might allocate development programs to countries with higher gender gaps in education and health [38]. Therefore, we assume that development programs that aim to contribute to gender equality should target those regions within a country in which a large fraction of the population is affected by vulnerability and gender inequalities. We employed four measures, all derived from census data, to capture vulnerability and gender-based inequalities in multiple aspects of life.

As the first indicator, we computed the percentage of female versus male household heads for a given municipality to capture vulnerable populations. Depending on the local context, female-headed households can be more vulnerable than male-headed households [84]. Colombia, for example, has witnessed a feminization of poverty in the past decades [85], especially in conflict-affected departments [86]. Female-headed households also often face multiple discriminations and are more vulnerable during times of conflict and in the post-conflict phase [87,88]. In Colombia, the proportion of female-headed households among IDPs, for example, was higher than the national average indicated by the census data [89].

To capture gender inequalities, we constructed three variables to reflect gender gaps in literacy, education and employment. Gender inequalities in education and employment are known to negatively impact productivity, economic growth and, consequently, development [83]. 
The choice of quantitative data on gender inequality, especially at the municipal level, is very limited, and thus we could only consider gender gaps in the areas of education and employment, using variables that are also considered essential for multidimensional well-being in Colombia [90]. The variables that capture these inequalities are constructed as ratios, where a value of $100 \%$ indicates gender balance, while a value greater than $100 \%$ indicates a higher number of females compared to males for the given characteristic. We compute the ratio of formally employed, educated (secondary level education), and literate women of working age (15-65 years) relative to the population of working-age males within each municipality. The indicator capturing formal employment indicates the access of women to the formal labor market. In Colombia, working in the formal sector is associated with several benefits, such as contributions to social security schemes [91]. Generally, women working in the informal economy tend to be exposed to more vulnerable situations [92]. The literacy indicator captures the existence of an effective primary education [93], while the completion of secondary education is a crucial prerequisite for advancing economic and social outcomes [94]. Summary statistics (Table 1) show that significantly fewer females are in formal employment, which is attributable to their role in child-care and domestic work and employment in the informal sector $[87,91,95]$. The statistics in the area of education show that females have generally higher levels of education than males, a confirmed global trend [96] known as the "reverse gender gap" in education [97], which in the case of Colombia has been connected to men's involvement in violent conflict [98]. While there is some local variation, we did not observe an overall gender gap in literacy (a value of $100 \%$ indicating gender balance), which is in line with prior studies [96]. Figure 3 provides maps of the graphical distribution of all gender variables.
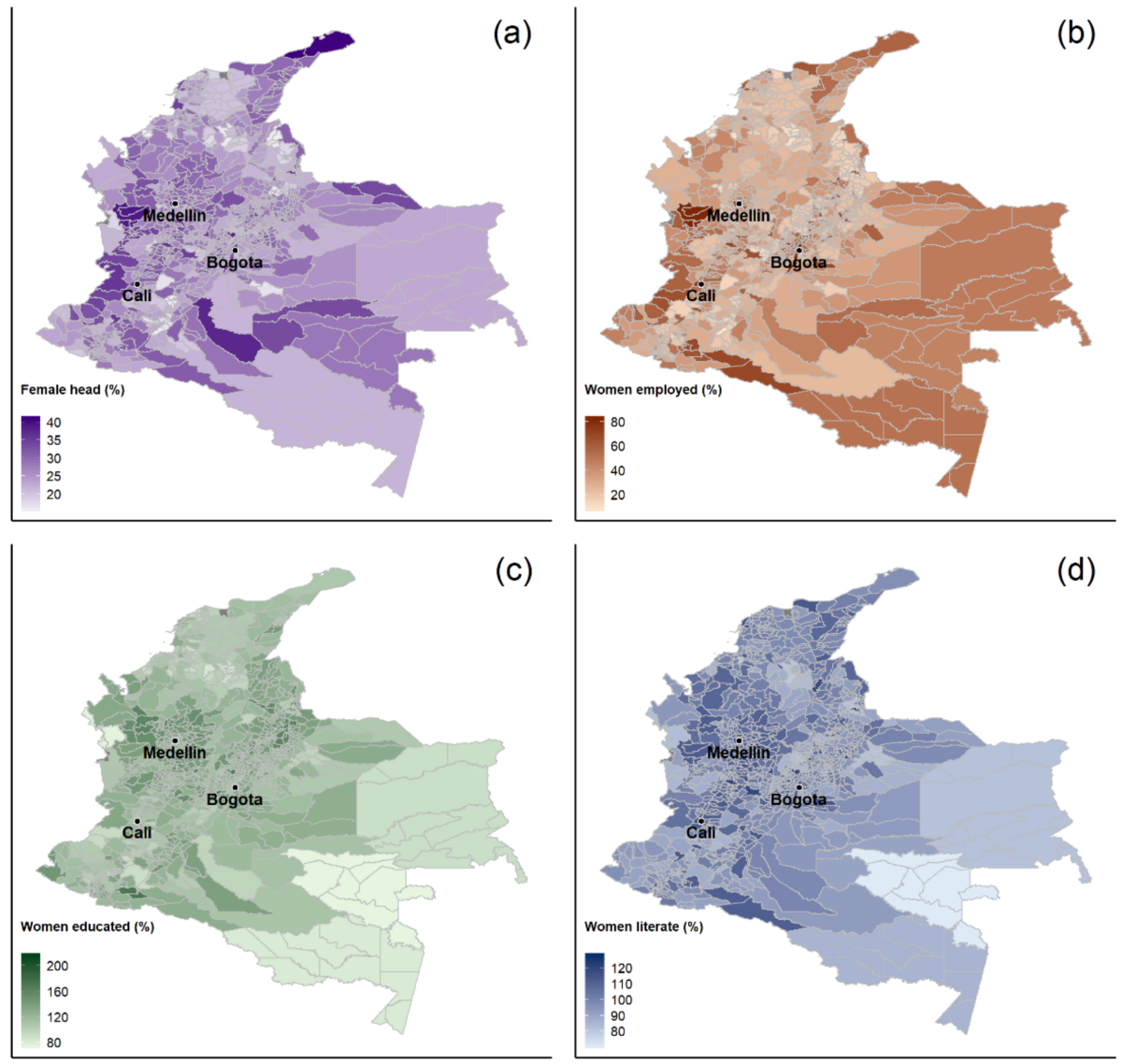

Figure 3. Geographic distribution of gender variables. Panel (a) indicates the percent of female headed households in a municipality. In panels $(\mathbf{b}-\mathbf{d})$, a value of $100 \%$ indicates gender balance (same number of males and females) while a value $>100 \%$ indicates higher numbers of females compared to males for the given characteristic; maps are oriented so that the top faces north. 
Table 1. Summary statistics table.

\begin{tabular}{|c|c|c|c|c|c|c|c|}
\hline & Unit & $\mathbf{N}$ & Min & Max & Mean & SD & Source \\
\hline \multicolumn{8}{|c|}{ Outcome variables } \\
\hline All projects & count & 1120 & 0 & 42 & 1.55 & 3.14 & AIMS \\
\hline CP projects & count & 1120 & 0 & 10 & 0.11 & 0.53 & AIMS \\
\hline W projects & count & 1120 & 0 & 3 & 0.09 & 0.3 & AIMS \\
\hline GG projects & count & 1120 & 0 & 4 & 0.06 & 0.32 & DEval \\
\hline \multicolumn{8}{|c|}{ Predictor variables } \\
\hline & \multicolumn{6}{|c|}{ Gender variables } & UCDP \\
\hline Female head & $\%$ & 1118 & 15.74 & 41.01 & 25.82 & 4.22 & IPUMSI \\
\hline $\begin{array}{l}\text { Women } \\
\text { employed }\end{array}$ & $\%$ & 1118 & 8.1 & 82.55 & 33.64 & 13.61 & IPUMSI \\
\hline $\begin{array}{l}\text { Women } \\
\text { educated }\end{array}$ & $\%$ & 1118 & 73.99 & 216.09 & 123.01 & 17.58 & IPUMSI \\
\hline $\begin{array}{l}\text { Women } \\
\text { literate }\end{array}$ & $\%$ & 1118 & 70.53 & 127.8 & 98.74 & 8.67 & IPUMSI \\
\hline \multicolumn{8}{|c|}{ Control variables } \\
\hline $\begin{array}{l}\text { Administrative } \\
\text { performance }\end{array}$ & index & 1101 & 30.36 & 88.53 & 65.16 & 9.76 & DNP \\
\hline $\begin{array}{c}\text { Average } \\
\text { precipitation }\end{array}$ & $\mathrm{mm}$ & 1117 & 31.43 & 518.43 & 133.44 & 73.63 & GeoQuery \\
\hline $\begin{array}{c}\text { Average } \\
\text { temperature }\end{array}$ & deg. C & 1117 & 8.31 & 31.9 & 22 & 5.44 & GeoQuery \\
\hline $\begin{array}{l}\text { Distance to } \\
\text { road }\end{array}$ & $\mathrm{km}$ & 1118 & 0.45 & 173.97 & 7.61 & 17.44 & GeoQuery \\
\hline $\begin{array}{l}\text { Night-time } \\
\text { lights }\end{array}$ & $\begin{array}{l}\text { nanoWatt/ } \\
\mathrm{cm}^{2} / \mathrm{sr}\end{array}$ & 1120 & 0 & 36.33 & 0.55 & 2.37 & NOAA \\
\hline $\begin{array}{c}\text { Coca } \\
\text { production }\end{array}$ & $1 / 0$ & 1120 & 0 & 1 & 0.15 & 0.36 & DRUG \\
\hline Wealth index & scale & 1118 & 1.24 & 8.83 & 5.78 & 1.36 & IPUMSI \\
\hline $\begin{array}{l}\text { Conflict } \\
\text { migrants }\end{array}$ & $\%$ & 1118 & 0.04 & 14.94 & 1.3 & 1.79 & IPUMSI \\
\hline $\begin{array}{l}\text { Young } \\
\text { children }\end{array}$ & count & 1118 & 0.14 & 0.81 & 0.3 & 0.09 & IPUMSI \\
\hline
\end{tabular}

Notes: Sources of variables: AIMS = Colombia Aid Information Management System (AIMS) [69]; DEval = German Institute for Development Evaluation; UCDP = Uppsala Conflict Data Project (UCDP) [71,72]; DNP = Colombian National Planning Department (DNP) [74]; GeoQuery = spatial data platform hosted by AidData [75]; NOAA = National Oceanic and Atmospheric Administration (NOAA) [76]; DRUG = DRUGDATA [99]; IPUMSI = IPUMS International census data access platform [73].

We employed a comprehensive set of sociodemographic and geographic variables to account for additional factors that may influence the allocation of development projects: administrative performance (performance index), environmental (precipitation, temperature, coca production), infrastructure (road distance, night-time lights), socioeconomic (wealth index), and demographic variables (conflict migrants, young children). Table 1 provides summary statistics and source information for all variables. Detailed information on the construction of the control variables and a correlation matrix can be found in the Appendices (Appendices A and F). Control variables were selected based on theoretical considerations and prior studies that have demonstrated the importance of these characteristics for the placement of development projects.

We modeled the count of development projects within each municipality. As the variable is characterized by many nulls, several low, and few high values, a Poisson distribution is commonly used for these types of models [13,100-102]. However, tests [103] revealed that our outcome variable is considerably overdispersed (variance $>$ mean), which can bias standard errors [104]. We therefore employed negative binomial models that 
incorporate a dispersion parameter theta $(\Theta)$ to account for overdispersion $[105,106]$. The negative binomial models take the following form (Equation (1)):

$$
\ln \left(\operatorname{prog}_{m d}\right)=\alpha+\beta_{1}\left(\ln (\text { battle deaths }+1)_{m d}\right)+\sum_{i}^{n} \beta_{i}\left(x_{m d}\right)+\gamma_{d}+\Theta+e
$$

Our model predicts the log $(\mathrm{ln})$ count of programs (prog) for each municipality $(m)$ located within a district $(d)$. The parameter $\alpha$ represents the conventional intercept, while the coefficient $\beta 1$ shows the effect of an increase in logged battle deaths on the number of development programs in a certain municipality. The model also accounts for the effects $(\beta)$ of various characteristics $(x)$ that may influence the allocation of a program to a certain municipality, including the four gender variables. We account for unobserved characteristics of districts (first administrative level, $\mathrm{N}=32$ ), by including district-level fixed effects $(\gamma d)$, and also clustering standard errors using the Huber-White method $[107,108]$. The district-level fixed effects also partly account for the increasing similarity of neighboring municipalities with decreasing distance. Finally, parameter e reflects the normally distributed residual variance.

When we restricted our outcome variable to a certain type of project (e.g., CP projects, W projects, or GG projects), the count of projects for each municipality declined substantially, resulting in numeric instabilities when estimating the negative binomial models. As such, we dichotomized the outcome variables and employed logit models to model the $\log$ odds of allocating at least one development project to a certain municipality, following Equation (2) [109].

$$
\begin{aligned}
\operatorname{logit}_{\left(\operatorname { P r } \left(\operatorname{prog}_{m d}\right.\right.} & >0)) \\
& =\alpha+\beta_{1}\left(\ln (\text { battle deaths }+1)_{m d}\right)+\sum_{i}^{n} \beta_{i}\left(x_{m d}\right)+\gamma_{d}+e
\end{aligned}
$$

In this study, we assumed a unidirectional causal relationship between battle deaths and development projects. While in some cases it may be possible, we considered it unlikely in the Colombian case that the placement of development projects caused an increase in battle deaths $[5,6,110]$. More importantly, the count of battle deaths (1994-2004) predates the post-conflict period during which development projects started their implementation (2006-2013 for AIMS data; 2012-2018 for DEval data). Based on this clear time order, we assumed a unidirectional causal relationship in which battle deaths influenced the placement of projects (battle deaths $->$ project placement). The use of a comprehensive set of control variables allowed us to further condition the observed relationships in an attempt to approximate causality.

\section{Results}

\subsection{All Projects}

As the first step of our analysis, we attempted to answer the research question (RQ1): Are international development programs located in regions that have historically experienced conflict in Colombia? Our negative binomial regression models, using "all projects" as the outcome variable, reveal a positive relationship between the log count of battle deaths and the number of development projects (Table 2). Model 1 includes only battle deaths, model 2 adds gender variables, and model 3 includes the full set of control variables. For a focused results exposition we do not discuss coefficients of control variables.

Conditional on all other effects, we find that an increase in battle deaths by one log unit increases the number of development projects in a municipality by $1.3(\exp (0.26))$ $(\mathrm{b}=0.26, p<0.001)$. 
Table 2. Results from negative binomial models estimating the relationship between battle deaths and all development projects in Colombia.

\begin{tabular}{|c|c|c|c|c|c|c|}
\hline & Model 1 & & Model 2 & & Model 3 & \\
\hline & $\mathbf{b}$ & sig. & b & sig. & b & sig. \\
\hline Intercept & 0.09 & & 0.27 & & -1.58 & \\
\hline Battle deaths & 0.33 & $* * *$ & 0.29 & $* * *$ & 0.26 & $* * *$ \\
\hline Female head $^{\mathrm{a}}$ & & & -0.01 & & 0.25 & \\
\hline Women employed a & & & 0.3 & $* * *$ & 0.14 & * \\
\hline Women educated ${ }^{\mathrm{a}}$ & & & -0.04 & & -0.02 & \\
\hline Women literate ${ }^{a}$ & & & -0.05 & & -0.08 & \\
\hline Administrative performance ${ }^{a}$ & & & & & 0.14 & + \\
\hline Average precipitation & & & & & 0.06 & \\
\hline Average temperature & & & & & 0.02 & \\
\hline Distance to road & & & & & 0.02 & ** \\
\hline Night-time lights & & & & & 0.14 & * \\
\hline Coca production & & & & & 0.25 & \\
\hline Wealth index & & & & & 0.02 & \\
\hline Conflict migrants ${ }^{\text {a }}$ & & & & & -0.13 & \\
\hline Young children & & & & & 1.14 & \\
\hline \multicolumn{7}{|l|}{ Model statistics } \\
\hline Theta & 2.02 & & 2.97 & & 3.51 & \\
\hline Pseudo R2 & 0.38 & & 0.46 & & 0.49 & \\
\hline AIC & 3381 & & 3251 & & 3186 & \\
\hline $\mathrm{N}$ & 1120 & & 1118 & & 1097 & \\
\hline
\end{tabular}

Notes: All models include department-level fixed effects; battle deaths were log-transformed to approximate a normal distribution; ${ }^{a}$ Coefficients reflect an incremental change of 10 units; negative binomial models; Development projects started implementation during the years 2006-2013; Conflict data for years 1994-2004; A value $<2.3$ on the variance inflation factor (vif) indicated that multicollinearity did not bias the estimates [111]; $+=p<0.1$; ${ }^{*}=p<0.05 ;{ }^{* *}=p<0.01 ;{ }^{* * *}=p<0.001$.

For the gender variables, only employment is significantly associated with the placement of development projects. Specifically, a 10\% increase in the number of females versus males in formal employment increases the number of development projects in the average municipality by $1.2(\mathrm{~b}=0.14 ; p<0.05)$.

\subsection{Projects with Gender as a Significant Objective}

In the next step of our analysis, we focus on specific types of projects to answer our second research question (RQ2): Are development projects with gender as a significant objective located in regions that have historically experienced conflict in Colombia? We estimated three separate models for conflict prevention (CP) projects (Model 1, AIMS data), projects focused on women (W) (Model 2, AIMS data), and German-funded projects with gender as a significant objective (GG) (Model 3, DEval data). The results (Table 3) show that $\mathrm{CP}$ projects tend to be located in municipalities for which a high number of battle deaths were reported $(b=0.65 ; p<0.001)$. This model serves as a positive control as we would expect the placement of conflict prevention projects specifically in conflict-prone regions.

Table 3. Results from logit models estimating the relationship between battle deaths and specific types of development projects in Colombia.

\begin{tabular}{ccccccc}
\hline & \multicolumn{2}{c}{ Model 1 } & \multicolumn{2}{c}{ Model 2 } & \multicolumn{2}{c}{ Model 3 } \\
\hline & \multicolumn{2}{c}{ CP Projects } & \multicolumn{2}{c}{ W Projects } & \multicolumn{2}{c}{ GG Projects } \\
& b & sig. & b & sig. & b & sig. \\
\hline Intercept & -3.35 & & -0.63 & & -29.09 & $* * *$ \\
Battle deaths & 0.65 & $* * *$ & 0.19 & $* *$ & 0.37 & $* *$ \\
Female head $^{\text {a }}$ & 0.3 & & -0.14 & & 0.04 & \\
\hline
\end{tabular}


Table 3. Cont.

\begin{tabular}{|c|c|c|c|c|c|c|}
\hline & \multicolumn{2}{|c|}{ Model 1} & \multicolumn{2}{|c|}{ Model 2} & \multicolumn{2}{|c|}{ Model 3} \\
\hline & \multicolumn{2}{|c|}{ CP Projects } & \multicolumn{2}{|c|}{ W Projects } & \multicolumn{2}{|c|}{ GG Projects } \\
\hline & $\mathbf{b}$ & sig. & $\mathbf{b}$ & sig. & $\mathbf{b}$ & sig. \\
\hline Women employed ${ }^{\mathrm{a}}$ & 0.24 & & 0.38 & & 0.39 & \\
\hline Women educated ${ }^{\mathrm{a}}$ & -0.04 & & 0.18 & & -0.08 & \\
\hline Women literate ${ }^{\mathrm{a}}$ & -0.2 & & 0.1 & & 0.53 & \\
\hline Administrative performance ${ }^{a}$ & 0.17 & & 0.38 & & 0.63 & \\
\hline Average precipitation & 0.17 & & -0.95 & & 0.91 & + \\
\hline Average temperature & 0 & & 0.05 & & -0.05 & \\
\hline Distance to road & 0.05 & * & 0.1 & & 0.02 & \\
\hline Night-time lights & 0.41 & * & 0.15 & & 0.21 & + \\
\hline Coca production & -0.14 & & -1.65 & & -0.25 & \\
\hline Wealth index & -0.16 & & -0.8 & $* *$ & -0.58 & \\
\hline Conflict migrants ${ }^{\text {a }}$ & 0.33 & & -3.97 & + & 0.04 & \\
\hline Young children & 4 & + & -3.13 & & -2.45 & \\
\hline \multicolumn{7}{|l|}{ Model statistics } \\
\hline Pseudo R2 & 0.36 & & 0.55 & & 0.5 & \\
\hline AIC & 478 & & 377 & & 305 & \\
\hline $\mathrm{N}$ & 1097 & & 1097 & & 1097 & \\
\hline
\end{tabular}

Notes: All models include department-level fixed effects; standard errors were clustered by departments using Huber-White adjustments $[107,108]$; battle deaths were log-transformed to approximate a normal distribution ${ }^{\text {a }}$ Coefficients reflect an incremental change of 10 units; Logit models; $\mathrm{CP}$ and $\mathrm{W}$ projects started implementing during the years 2006-2013; GG projects started implementing during the years 2012-2018; Conflict data for years 1994-2004; $+=p<0.1 ;^{*}=p<0.05 ;{ }^{* *}=p<0.01 ;{ }^{* * *}=p<0.001$.

For both, $\mathrm{W}$ projects $(\mathrm{b}=0.19 ; p<0.01)$ and GG projects $(\mathrm{b}=0.37, p<0.01)$ we also observed a statistically significant positive relationship. An increase of battle deaths by one log unit increases the odds of observing a German-funded development project with gender as a significant objective being placed in the same municipality by $45 \%((\exp (0.37)-1) \times 100)$.

\subsection{Interactions}

In a final analytical step, we addressed our third research question (RQ3): Can gender characteristics of the population explain the relationship between conflicts and geographic allocation of development programs? To answer this question, we used interactions between battle deaths and the four gender variables (Table 4). As a first observation, the placement of $\mathrm{CP}$ projects in post-conflict regions does not seem to systematically vary conditional on the gender context, as evident from insignificant interaction terms. However, conditional effects do emerge for all projects, $\mathrm{W}$ projects, and are suggestive (marginally significant) for GG projects. To illustrate these interactions, Figure 4 depicts predicted probabilities when interacting the percentage of female household heads with battle deaths.

Table 4. Results from models estimating the interaction between battle deaths and gender variables in predicting the allocation of development projects across Colombia.

\begin{tabular}{ccccccccc}
\hline & All Projects & \multicolumn{1}{c}{ CP Projects } & \multicolumn{2}{c}{ W Projects } & \multicolumn{2}{c}{ GG Projects } \\
\hline & Model 1 & Model 2 & & Model 3 & & Model 4 & \\
& $\mathrm{b}$ & sig. & $\mathrm{b}$ & sig. & $\mathrm{b}$ & sig. & $\mathrm{b}$ & sig. \\
Battle deaths & 0.25 & $* * *$ & 0.65 & $* * *$ & 0.08 & & 0.38 & $* * *$ \\
Female head $\mathrm{a}$ & 0.17 & & 0.29 & & -0.48 & & -0.16 & \\
Battle deaths $\times$ & 0.13 & $* *$ & 0.01 & & 0.61 & $* * *$ & 0.27 \\
Female head & & & & & & & \\
\hline
\end{tabular}


Table 4. Cont.

\begin{tabular}{|c|c|c|c|c|c|c|c|c|}
\hline & \multicolumn{2}{|c|}{ All Projects } & \multicolumn{2}{|c|}{ CP Projects } & \multicolumn{2}{|c|}{ W Projects } & \multicolumn{2}{|c|}{ GG Projects } \\
\hline & Model 5 & & Model 6 & & Model 7 & & Model 8 & \\
\hline & & sig. & $\mathrm{b}$ & sig. & $\mathrm{b}$ & sig. & b & sig. \\
\hline Battle deaths & 0.22 & $* * *$ & 0.66 & $* * *$ & 0.15 & + & 0.3 & + \\
\hline Women employed ${ }^{a}$ & 0.07 & & 0.26 & & 0.03 & & 0.29 & \\
\hline $\begin{array}{c}\text { Battle deaths } \times \\
\text { Women employed }\end{array}$ & 0.1 & $* * *$ & -0.02 & & 0.47 & $* * *$ & 0.2 & + \\
\hline & $\begin{array}{l}\text { Model } 9 \\
\mathrm{~b}\end{array}$ & sig. & $\begin{array}{l}\text { Model } 10 \\
\mathrm{~b}\end{array}$ & sig. & $\begin{array}{l}\text { Model } 11 \\
\mathrm{~b}\end{array}$ & sig. & $\begin{array}{l}\text { Model } 12 \\
\mathrm{~b}\end{array}$ & sig. \\
\hline Battle deaths & 0.26 & $* * *$ & 0.64 & $* * *$ & 0.21 & $* *$ & 0.36 & $* *$ \\
\hline Women educated ${ }^{a}$ & -0.01 & & 0 & & 0.2 & + & 0.02 & \\
\hline $\begin{array}{l}\text { Battle deaths } \times \\
\text { Women educated }\end{array}$ & -0.02 & & -0.03 & & -0.03 & & -0.1 & \\
\hline & $\begin{array}{c}\text { Model } 13 \\
\text { b }\end{array}$ & sig. & $\begin{array}{l}\text { Model } 14 \\
\text { b }\end{array}$ & sig. & $\begin{array}{l}\text { Model } 15 \\
\text { b }\end{array}$ & sig. & $\begin{array}{l}\text { Model } 16 \\
\mathrm{~b}\end{array}$ & sig. \\
\hline Battle deaths & 0.24 & $* * *$ & 0.64 & $* * *$ & 0.09 & & 0.36 & $*$ \\
\hline Women literate ${ }^{a}$ & -0.09 & & -0.22 & & -0.07 & & 0.41 & \\
\hline $\begin{array}{l}\text { Battle deaths } \times \\
\text { Women literate }\end{array}$ & 0.12 & $* * *$ & 0.02 & & 0.22 & & 0.16 & + \\
\hline
\end{tabular}

Notes: Models control for all variables employed in Table 2 (not shown for improved readability) and include department-level fixed effects; battle deaths were log-transformed to approximate a normal distribution; variables involved in the interactions were grand mean centered; ${ }^{a}$ Coefficients reflect an incremental change of 10 units; All projects: Negative binomial models; conflict prevention $(\mathrm{CP})$ projects, women $(\mathrm{W})$ projects, and Germanfunded projects with gender as significant objective (GG): Logit models; $\mathrm{CP}$ and W projects started implementing during the years 2006-2013; GG projects started implementing during the years 2012-2018; conflict data for years $1994-2004 ;+=p<0.1 ;^{*}=p<0.05 ;{ }^{* *}=p<0.01 ; * * *=p<0.001$.

Figure $4 \mathrm{a}$ reveals an overall positive relationship between battle deaths and the predicted counts of all projects in a municipality ( $50 \%$ ile). The three lines indicate that the strength of the relationship (slope) is conditional on the percentage of female heads living in the given municipality. In municipalities with few female heads ( $10 \%$ ile), the slope of the line is flat, suggesting a weak relationship. Yet, as the proportion of female heads increases, the relationship (slope) becomes considerably more pronounced (e.g., 90th percentile).

This conditionality is even stronger for $\mathrm{W}$ projects (Figure 4c). Only in regions with many female household heads (90th percentile) do we see a strong positive relationship between the number of battle deaths and $\mathrm{W}$ projects. As such, projects focused on women do not gravitate towards post-conflict regions in general, but only when a high proportion of female heads is present in the communities. We observe similar significant positive interaction terms for the gender variables "women employed" and "women literate". The positive relationship between battle deaths and $\mathrm{W}$ projects becomes much stronger as the proportion of women (relative to men) formally employed and literate increases in the municipality.

\subsection{Robustness Tests}

We performed a number of robustness tests to explore the sensitivity of our results.

While the choice of models was based on the nature of the outcome variables (counts), it is possible to use more simplistic OLS models. While OLS models can produce valid results [112], their use is discouraged for count data with low mean values [113]. Moreover, OLS models would allow predictions of negative values, which is inappropriate for count variables of exclusively positive integers as in our case. Nevertheless, as a robustness test, we employed an OLS approach to estimate models of Tables 2 and 3 (Appendix B, Table A1). The effects of the primary predictor (conflict) remain similar in direction and significance, demonstrating the robustness of our findings to the choice of the model. 

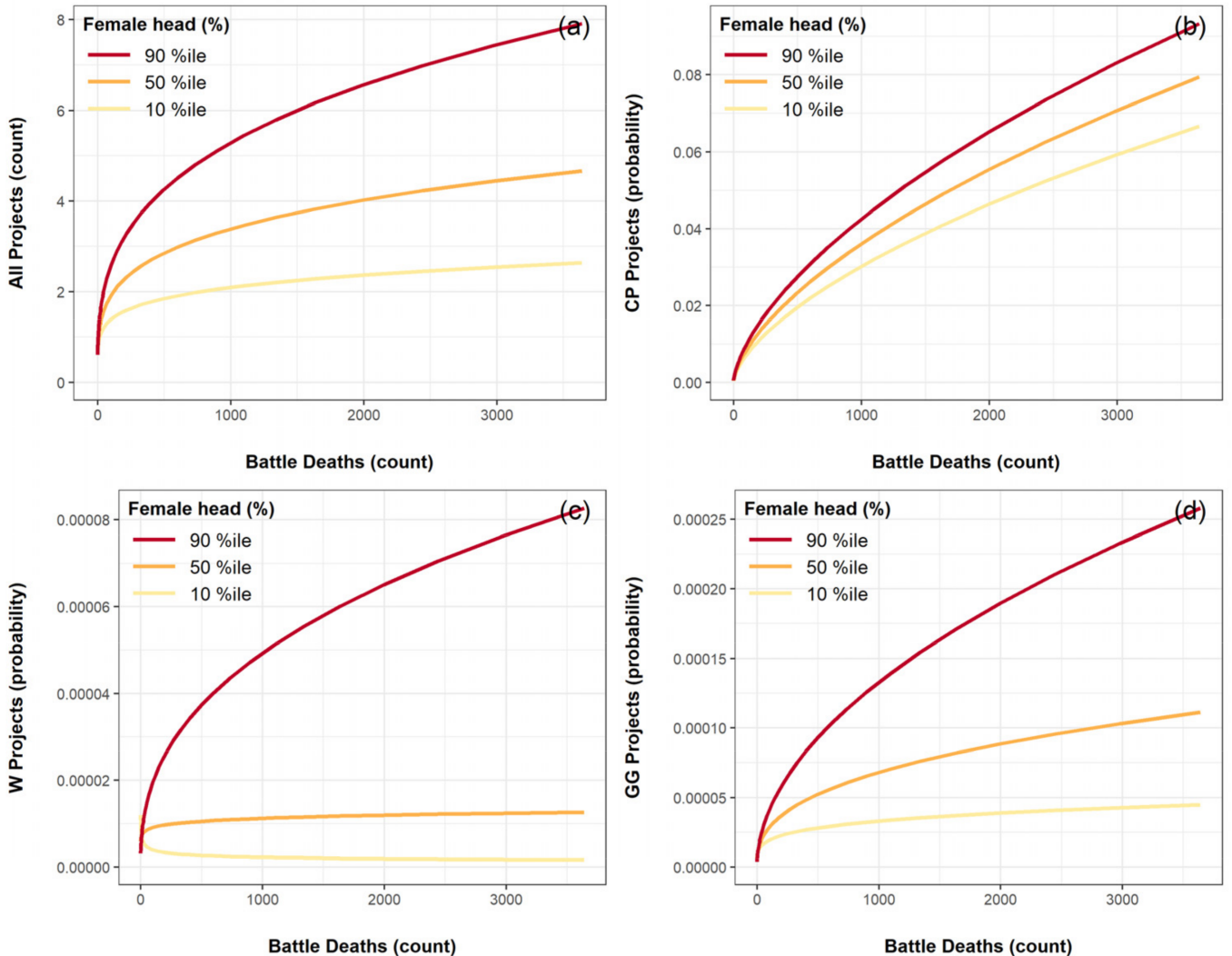

Figure 4. Visual representation of the interaction between battle deaths and the percentage of female heads by project type $((\mathbf{a})=$ All Projects; $(\mathbf{b})=$ CP Projects; $(\mathbf{c})=W$ Projects; $(\mathbf{d})=$ GG Projects $)$; predictions were generated for the average value of all other variables in the model; all projects: Negative binomial models; conflict prevention (CP) projects, projects focused on women (W), and German-funded projects with gender as significant objective (GG): Logit models; CP and W projects started implementing during the years 2006-2013; GG projects started implementing during the years 2012-2018; conflict data for years 1994-2004; $10 \%$ ile $=21 \%$ female household heads, $50 \%$ ile $=26 \%$ female household heads, $90 \%$ ile $=31 \%$ female household heads.

We selected the set of control variables based on their relevance to project placement, as suggested by theory and empirical studies. In addition to these theoretical considerations, we apply the method proposed by Oster [114] to assess the robustness of our models to unobserved variable bias. We find only a small change in the coefficient of the primary predictor (battle deaths) when adding control variables, accompanied by a substantial increase in R-squared. The Oster test suggests that unobserved variables would have to be almost five times $(\delta=4.8)$ as important as the observed variables for the effect of the primary predictor to drop to zero. This indicates that bias due to unobserved confounders is highly unlikely.

The AIMS data provide information on the monetary value of commitments for each project. While for our main analysis we preferred to use the number (count) of projects per municipality, we also estimated OLS regressions using commitments as outcome variables. The results from the commitment models (Appendix C, Table A2) are highly similar to the results from the project count models, indicating an increase in aid spending in regions most affected by conflict.

In the main analysis, we use the 10-year period of high-intensity conflict from 1994-2004. To investigate if a change to the length of this period affects our results, we used all available battle deaths information in the UCDP data for the period from 1989-2018. Re-estimating the models of Table 2 using this alternative predictor produces very similar results, further confirming the robustness of our findings (Appendix D, Table A3). 
To investigate potential impacts of influential cases, a jackknife type procedure was performed, removing a random selection of $10 \%$ of all municipalities $(\mathrm{N}=1120)$ from the sample and re-estimating the models following an established procedure $[115,116]$. The resampling was performed 1000 times and the percentage of significant results was recorded. We varied the number of randomly omitted municipalities between $10 \%$ and 30\% (Appendix E, Table A4). These tests demonstrated that the obtained results are highly robust and not caused by outliers.

\section{Discussion and Conclusions}

In this study, we have investigated the relationship between the location of development intervention projects and conflict in Colombia. The observed results for development projects, in general, are in line with our theoretical expectations, and with recent observations, suggesting an increased development activity in post-conflict regions [117]. As an example, the Colombian peace process provided an incentive for implementing more programs to reintegrate ex-combatants and to prevent future conflicts $[118,119]$. We also find more development projects in regions with higher numbers of women formally employed. Likely, this relationship reflects the efforts of many development projects to support vulnerable populations such as displaced women [58,120], with positive effects on the female employment rate.

Moreover, our results confirm that projects with gender as a significant objective tend to gravitate towards post-conflict regions. This observation can be explained by donor priorities of funding programs to support female war victims [58,121-123] and to promote peace through female empowerment $[44,124,125]$ or by efforts to contribute to the implementation of UNSCR 1325 [126].

Finally, the observed interactions suggest that the placement of development projects in post-conflict regions is strongest in the presence of a large number of female-headed households, as well as in high formal employment and literacy rates for women. Rather than telling a story of vulnerability, these findings hint at increased female activism and power. Literate and formally employed women are in a much better position to lobby for the placement of new development projects in their respective communities [127,128]. Indeed, women in Colombia have demonstrated strong community engagement, often supported by international development programs [45]. Moreover, women have been at the frontline of countrywide peace movements, uniting in large multi-ethnic groups to raise their voices for gender justice throughout the peace negotiations [44,129]. Here, they ensured that gender issues were included in the peace treaty to prevent the replication of male dominance [130]. As such, the observed conditionality may be explained by a culture of strong female leadership, self-organization, and lobbying for the placement of development projects in certain regions [44,45,125,131].

While thoroughly conducted, this study is not without limitations. First, data limitations prevented us from using information on gender-based violence from Demographic and Health Surveys (DHS). Future research may use sophisticated geospatial interpolation techniques to estimate these gender characteristics for municipalities in which the DHS survey was not fielded [132].

Second, we drew on the available published literature to explain the conditional relationships within the context of Colombia. Future research may employ qualitative methods such as interviews and focus groups to provide a better understanding of the mechanisms that amplify the project placement in post-conflict regions in the presence of a large number of female household heads, and a large proportion of employed and literate women.

A gender focus in post-conflict recovery programs can be beneficial for several reasons. Women and girls were severely affected by the conflict $[56,59,89,131,133]$, resulting in comparatively high levels of forced internal displacement $[89,133]$. Violent conflicts often claim the lives of husbands and fathers, leaving behind mothers and daughters who are at increased risk of poverty and marginalization [134-136]. As such, the international 
development community could build on the trends observed in this study and further strengthen the gender focus in post-conflict recovery programs in line with the recommendations of the United Nations Security Council Resolution 1325 on women, peace and security [60].

The pertinent literature and our findings suggest an active role in advocacy and lobbying by strong Colombian women who act as community mobilizers [44,45,125,135]. Yet, in the spirit of "leaving no one behind" [62], donor agencies could increase their implementation of gender-focused projects in post-conflict regions that are characterized by limited education and literacy of females. These locations likely lack the female leadership and lobbying activities that tend to attract the support of donor agencies and, as a result, may be neglected in the distribution of program resources.

In sum, an increased focus on women's needs [134], but at the same time recognizing women as important allies and partners [137], will allow the international development community to implement the UN Security Council resolution 1325 and to more fully advance the Agenda 2030 targets [62] for gender equality (SDG \#5) and peace, justice and strong institutions (SDG \#16), as well as to further the equal treatment of all human beings, even under the harsh societal conditions faced by those in conflict or post-conflict settings.

Author Contributions: Conceptualization, R.J.N. and V.G.; methodology, R.J.N. and T.W.; software, R.J.N., T.W. and J.B.; validation, R.J.N., T.W. and J.B.; formal analysis, R.J.N.; investigation, R.J.N. and J.B.; resources, V.G. and S.B.-S.; data curation, R.J.N., T.W. and J.B.; writing-original draft preparation, R.J.N., V.G., J.B., T.W., S.B.-S.; writing-review and editing, R.J.N., V.G., J.B., T.W., S.B.-S.; visualization, R.J.N. and J.B.; supervision, R.J.N. and V.G.; project administration, R.J.N. and V.G. All authors have read and agreed to the published version of the manuscript.

Funding: This research received no external funding.

Institutional Review Board Statement: Not applicable.

Informed Consent Statement: Not applicable.

Data Availability Statement: Most data presented in this study are openly available from the cited sources. The data on Germany-funded project locations are available from the corresponding author in anonymized form aggregated to the first subnational level due to the sensitive nature of precise project locations.

Acknowledgments: We are indebted to Nikolas Schöneck for help with the manually coding of project locations. We are grateful to Cristina Garcia for her help with background research on the Colombian context. Special thanks to Sven Harten and Martin Noltze for insightful comments on the initial draft of this manuscript. We also thank two anonymous reviewers and the editors for helpful suggestions to improve the quality of this article.

Conflicts of Interest: The authors declare that they have no conflicts of interest.

\section{Appendix A}

Mediator and control variables employed in the main text were constructed as outlined in the following paragraphs:

Administrative performance. Project placement takes place within the nexus of potentially conflicting donor priorities: seeking to assist the neediest but finding it more effective, and therefore preferable, to work with capable administrations [22,29,138,139]. In this study, we attempt to capture these tendencies with the index known as Desempeño Integral Municipal, which constitutes a comprehensive assessment of the administrative performance of each municipality [74]. The index reflects the equally weighted mean of four indicators: administrative effectiveness, administrative efficiency, compliance with legal requirements, and quality of management. The index is available for the years 2006-2017, and we calculated the mean to reflect average performance across time. 
Environment. Development projects may be systematically allocated due to specific environmental conditions. For example, in line with the recipient need model, climate change adaptation programs may target regions particularly vulnerable to flooding or droughts $[140,141]$. Yet, other factors may influence this relationship. For example, conflict migrants may settle in structures and regions particularly vulnerable to environmental impacts (e.g., make-shift housing on steep hillsides) leading to an increased need for development interventions [142,143].

To capture differences in climatic impacts, we use a measure of annual average precipitation $(\mathrm{mm})$ and annual average air temperature $\left({ }^{\circ} \mathrm{C}\right)$ for the year 2017 derived from gridded data (50 km spatial resolution) compiled by the University of Delaware [144] and available as municipality aggregates via AidData's GeoQuery [75].

Coca production. Colombia's extensive coca economy has been key to sustaining military conflict, notably in FARC-controlled regions [145]. In the major coca-growing areas, violence tends to be higher compared to non-producing regions [146,147]. At the same time, coca cultivation often relies upon the labor of rural women, who, despite increasing security threats, often benefit economically [148]. In this context, development programs seek to provide these women with alternative livelihood options to ease their dependence on illicit crop production $[149,150]$. Given the connection between coca production, conflict, and development projects, we make use of data on coca production sites for the period 1980-2002 generated by Buhaug and Lujala [99]. We constructed a dummy variable, differentiating between municipalities in which coca was produced (coded 1) and municipalities that did not have coca production (coded 0$)$.

Infrastructure. In development studies, access to quality infrastructure is widely recognized as fundamental in achieving development targets such as economic growth and reduced inequality [151]. In this study, we account for the level of infrastructure development using two measures: (1) the distance to the next road, and (2) nightly luminescence. The distance to the next road (in $\mathrm{km}$ ) was computed based on the Global Roads Open Access Dataset (gRoads) version 1.0. [152] and aggregated to the municipality using the GeoQuery system [75]. Gridded data (spatial resolution: 15 arc-seconds or $300 \mathrm{~m}$ ) of nocturnal luminescence (night-time lights) from the Visible Infrared Imaging Radiometer Suite (VIIRS) Day/Night Band (DNB) is publicly available from the US National Oceanic and Atmospheric Administration (NOAA) [76]. We employed the cloud masked, outlier-removed composite data (vcm-orm-ntl) for the year 2016. Values were aggregated to the municipality level and reflect luminescence in nanoWatts $/ \mathrm{cm}^{2} / \mathrm{sr}$. Prior research has used night-time lights to approximate economic growth and urbanization [153-157].

Socioeconomic context. Poverty alleviation is an important goal of development programs $[24,141]$. Assessments on resource allocation have demonstrated that poor regions and countries do indeed receive the largest aid inflows, although political interests also influence donor decisions [21,26,139,141,158].

To capture the overall socioeconomic status of a household, we constructed an additive wealth index in line with prior work $[159,160]$ based on census microdata. We first performed a factor analysis (rotation: "varimax") with 18 variables. Using a cut-off threshold of 0.4 eigenvalue, we identified nine variables that best reflect the latent construct of "wealth". These variables measure the structural quality of the housing unit (material of floor, number of bathrooms), the type and quality of services available at the residence (type of cooking fuel, toilet type, trash collection, access to electricity, access to piped water), as well as the possession of appliances (refrigerator, TV). We combined these variables to an additive wealth index (Cronbach's alpha $=0.88)$. 
Demographic characteristics. Colombia shows one of the highest rates of internally displaced people worldwide [161]. Displaced populations are highly vulnerable, often poor, and frequently lack access to basic social services [88]. It is therefore not surprising that numerous development programs in Colombia target people displaced by violent conflict [162-164]. Using census data, we constructed a variable that measures the proportion of conflict migrants (migration due to violence or insecurity) in each municipality. Prior research has used this variable to evaluate the impacts of forced migration on female empowerment [165] or to examine Colombia's internal migration patterns over the turn of the century [166].

Young children, in particular, have been suffering from the consequences of violent conflict in Colombia and have frequently experienced insecurity and emotional and physical abuse [167-170]. In response, several development agendas specifically target children's well-being in fragile contexts [171,172]. As such, we expected to find a larger number of development projects in regions with a high proportion of young children. We, therefore, constructed a variable based on census data that reflects the average number of young children (age < five years) per household within a municipality.

Initially, we included a measure for population density in our models, based on the assumption that projects may be more frequently located in populated regions. Yet, due to high correlation with our measure of night-time lights, we were unable to include both variables in the same model and decided to omit population density.

\section{Appendix B}

To investigate the sensitivity of the effects of conflict on project placement to the choice of the model, we estimated all models using OLS models. The direction and significance of the observed effects are similar to the results of the negative binomial and logit models, demonstrating the robustness of the observed effects to the choice of the model.

Table A1. Results from OLS regression models estimating the effect of conflict on placement of development projects.

\begin{tabular}{|c|c|c|c|c|c|c|c|c|}
\hline & \multicolumn{2}{|c|}{ Model 1} & \multicolumn{2}{|c|}{ Model 2} & \multicolumn{2}{|l|}{ Model 3} & \multicolumn{2}{|c|}{ Model 4} \\
\hline & \multicolumn{2}{|c|}{ All Projects } & \multicolumn{2}{|c|}{ CP Projects } & \multicolumn{2}{|c|}{ W Projects } & \multicolumn{2}{|c|}{ GG Projects } \\
\hline & $\mathbf{b}$ & sig. & $\mathbf{b}$ & sig. & $\mathbf{b}$ & sig. & $\mathbf{b}$ & sig. \\
\hline Intercept & 1.24 & & 0.11 & & 0.44 & $* *$ & -0.21 & \\
\hline Battle deaths & 0.58 & $* * *$ & 0.05 & $* * *$ & 0.01 & + & 0.01 & * \\
\hline Female head $^{\mathrm{a}}$ & 0.55 & & 0.03 & & -0.01 & & 0.02 & \\
\hline Women employed ${ }^{a}$ & 0.57 & $* *$ & 0.02 & & 0.03 & + & 0.01 & \\
\hline Women educated ${ }^{a}$ & -0.01 & & 0 & & 0 & & 0 & \\
\hline Women literate ${ }^{\mathrm{a}}$ & -0.34 & & -0.02 & & -0.01 & & 0 & \\
\hline $\begin{array}{l}\text { Administrative } \\
\text { performance }^{a}\end{array}$ & 0.35 & + & 0.01 & & 0.02 & & 0.02 & \\
\hline Average precipitation & -0.06 & & 0 & & -0.05 & & 0.01 & \\
\hline Average temperature & 0.03 & & 0 & & 0 & & 0 & \\
\hline Distance to road & 0.05 & * & 0.01 & $* *$ & 0 & & 0 & \\
\hline Night-time lights & 0.36 & $* *$ & 0.03 & $* *$ & 0 & & 0.01 & + \\
\hline Coca production & 0.47 & & -0.01 & & -0.06 & & 0.01 & \\
\hline Wealth index & -0.3 & & -0.02 & & -0.02 & + & -0.01 & \\
\hline Conflict migrants ${ }^{a}$ & -0.09 & & -0.01 & & -0.16 & & 0.03 & \\
\hline Young children & 0.13 & & 0.31 & & -0.04 & & -0.06 & \\
\hline \multicolumn{9}{|l|}{ Model statistics } \\
\hline $\mathrm{R} 2$ & 0.32 & & 0.22 & & 0.41 & & 0.32 & \\
\hline AIC & 5312 & & 49 & & -205 & & -597 & \\
\hline $\mathrm{N}$ & 1097 & & 1097 & & 1097 & & 1097 & \\
\hline
\end{tabular}

Notes: Same model specifications used as in Tables 2 and 3 of the main text; ${ }^{\text {a }}$ Coefficients reflect an incremental

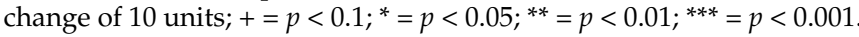




\section{Appendix C}

To investigate the sensitivity of our results to the specification of the outcome variable, we use the US dollar value of total commitments instead of the count of development projects. Table A2 shows results from OLS regression models.

Table A2. Results from OLS regression models estimating the effect of conflict on commitments (USD millions) for all development projects.

\begin{tabular}{|c|c|c|c|c|}
\hline & \multicolumn{2}{|c|}{ All Projects } & \multirow[b]{2}{*}{$\mathbf{b}$} & \multirow[b]{2}{*}{ sig } \\
\hline & $\mathbf{b}$ & sig. & & \\
\hline Intercept & 0.87 & ** & 3.09 & \\
\hline Battle deaths & 0.68 & $* * *$ & 0.57 & $* * *$ \\
\hline Female head ${ }^{\mathrm{a}}$ & & & 1.55 & \\
\hline Women employed ${ }^{a}$ & & & 0.62 & * \\
\hline Women educated a & & & 0.16 & \\
\hline Women literate ${ }^{a}$ & & & -0.95 & * \\
\hline Administrative performance $^{a}$ & & & -0.31 & \\
\hline Average precipitation & & & 0.02 & \\
\hline Average temperature & & & 0.06 & \\
\hline Distance to road & & & 0.05 & * \\
\hline Night-time lights & & & 0.19 & \\
\hline Coca production & & & 0.58 & \\
\hline Wealth index & & & -0.17 & \\
\hline Conflict migrants ${ }^{a}$ & & & 0.14 & \\
\hline Young children & & & 4.53 & \\
\hline \multicolumn{5}{|l|}{ Model statistics } \\
\hline R2 & 0.27 & & 0.32 & \\
\hline AIC & 6091 & & 5927 & \\
\hline $\mathrm{N}$ & 1120 & & 1097 & \\
\hline
\end{tabular}

Notes: Same model specifications used as in Table 2 of the main text; ${ }^{\text {a }}$ Coefficients reflect an incremental change of 10 units; $+=p<0.1 ;^{*}=p<0.05 ;^{* *}=p<0.01 ;{ }^{* * *}=p<0.001$.

\section{Appendix D}

In the primary analysis of this study, we use the period 1994-2004 to capture highconflict intensity. To investigate the sensitivity of our analysis to changes in this period, we used the entire period from 1989-2018 for which battle-related deaths ("battle deaths") are recorded in the UCDP database. Results from negative binomial models are shown in Table A3.

Table A3. Results from negative binomial models estimating the relationship between battle deaths (1989-2018) and all development projects in Colombia.

\begin{tabular}{ccccc}
\hline & Model 1 & \multicolumn{3}{c}{ Model 2 } \\
& All Projects & & \\
& b & sig. & b & sig. \\
\hline Intercept $^{\text {Battle deaths }}$ & -0.05 & & -1.6 & \\
Female head $^{\text {a }}$ & 0.34 & $* * *$ & 0.28 & $* * *$ \\
Women employed $^{\text {a }}$ & & & 0.24 & \\
Women educated $^{\text {a }}$ & & 0.13 & $*$ \\
Women literate $^{\text {a }}$ & & -0.02 & \\
Administrative performance $^{\text {a }}$ & & -0.08 & + \\
Average precipitation & & 0.14 & \\
\hline
\end{tabular}


Table A3. Cont.

\begin{tabular}{|c|c|c|c|c|}
\hline & \multicolumn{2}{|l|}{ Model 1} & \multicolumn{2}{|c|}{ Model 2} \\
\hline \multicolumn{5}{|c|}{ All Projects } \\
\hline & b & sig. & $\mathbf{b}$ & sig. \\
\hline Average temperature & & & 0.02 & \\
\hline Distance to road & & & 0.02 & $* *$ \\
\hline Night-time lights & & & 0.15 & $* *$ \\
\hline Coca production & & & 0.18 & \\
\hline Wealth index & & & 0.01 & \\
\hline Conflict migrants a & & & -0.13 & \\
\hline Young children & & & 1.02 & \\
\hline \multicolumn{5}{|l|}{ Model statistics } \\
\hline Theta & 2.14 & & 3.78 & \\
\hline Pseudo R2 & 0.4 & & 0.51 & \\
\hline AIC & 3355 & & 3158 & \\
\hline $\mathrm{N}$ & 1120 & & 1097 & \\
\hline
\end{tabular}

Notes: Same model specifications used as in Table 2 of the main text; ${ }^{\text {a }}$ Coefficients reflect an incremental change

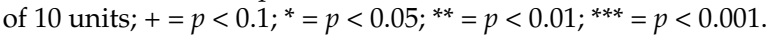

\section{Appendix E}

To investigate the effect of influential cases on our results, we performed a Jackknife type resampling procedure. Omitting a random sample between $10 \%$ and $30 \%$ of all municipalities and re-estimating the models 1000 times produced the following table (Table A4). The table records the percentage that a significant coefficient for battle deaths (\% sig) was returned when repeatedly re-estimating the model.

Table A4. Jack-knife type procedure to test the robustness of the obtained estimates.

\begin{tabular}{|c|c|c|c|c|c|c|c|c|c|c|c|c|c|c|c|c|}
\hline & \multicolumn{2}{|c|}{$\begin{array}{c}\text { All } \\
\text { Projects }\end{array}$} & \multicolumn{6}{|c|}{$\begin{array}{c}\mathrm{CP} \\
\text { Projects }\end{array}$} & \multicolumn{2}{|c|}{$\begin{array}{c}\text { W } \\
\text { Projects }\end{array}$} & \multicolumn{6}{|c|}{$\begin{array}{c}\text { GG } \\
\text { Projects }\end{array}$} \\
\hline & $\mathbf{b}$ & sig. & $\begin{array}{c}\% \\
\text { omitted }\end{array}$ & $\begin{array}{c}\% \\
\text { sig. }\end{array}$ & $\mathbf{b}$ & sig. & $\begin{array}{c}\% \\
\text { omitted }\end{array}$ & $\begin{array}{c}\% \\
\text { sig. }\end{array}$ & $\mathbf{b}$ & sig. & $\begin{array}{c}\% \\
\text { omitted }\end{array}$ & $\begin{array}{l}\% \\
\text { sig. }\end{array}$ & $\mathbf{b}$ & sig. & $\begin{array}{c}\% \\
\text { omitted }\end{array}$ & $\begin{array}{r}\% \\
\text { sig. }\end{array}$ \\
\hline \multirow{3}{*}{$\begin{array}{l}\text { Battle } \\
\text { deaths }\end{array}$} & 0.26 & $* * *$ & 10 & 100 & 0.65 & $* * *$ & 10 & 100 & 0.19 & $* *$ & 10 & 77 & 0.37 & $* *$ & 10 & 93.8 \\
\hline & & & 20 & 100 & & & 20 & 100 & & & 20 & 62.8 & & & 20 & 78.1 \\
\hline & & & 30 & 100 & & & 30 & 100 & & & 30 & 50 & & & 30 & 63 \\
\hline
\end{tabular}

Notes: Same model specifications used as in Tables 2 and 3 of the main text; Control variables not shown for improved focus of the table; $+=p<0.1 ;^{*}=p<0.05 ;^{* *}=p<0.01 ;{ }^{* * *}=p<0.001$.

The results show that for all projects and conflict prevention $(\mathrm{CP})$ projects the significant relationship with battle deaths stayed significant $100 \%$ of the time. For projects focused on women, (W) the coefficient reached significance in $77 \%$ of the model estimates and for German-funded gender-focused projects it reached significance in $94 \%$ of the estimates, indicating an overall high level of robustness of the estimates.

\section{Appendix F}

In order to permit an evaluation of the correlation between relevant variables of the analysis, we provide a histogram (Figure A1). 


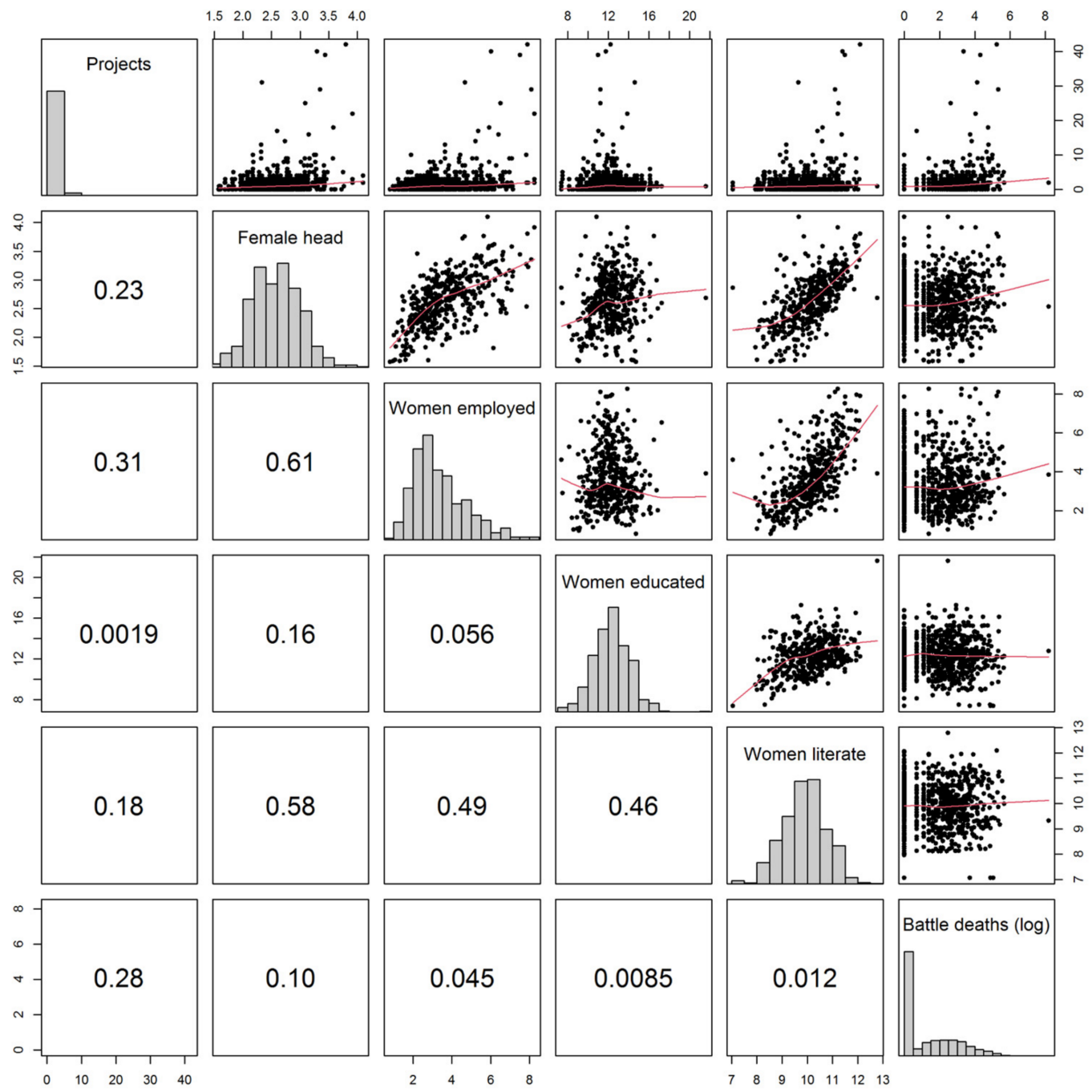

Figure A1. Scatterplots, histograms and Pearson's correlation coefficient for the main outcome variable, project, the main predictor, battle deaths, and the gender variables.

\section{References}

1. Pettersson, T.; Öberg, M. Organized Violence, 1989-2019. J. Peace Res. 2020, 57, 597-613. [CrossRef]

2. OECD. States of Fragility 2018; OECD: Paris, France, 2018; ISBN 978-92-64-30206-8.

3. Wolff, J.; Witt, A.; Stappenbeck, J.; Peez, A.; Junk, J.; Coni-Zimmer, M.; Christian, B.; Birchinger, S.; Bethke, F. Frieden und Entwicklung 2020: Eine Analyse Aktueller Erfahrungen und Erkenntnisse; Leibniz-Institut, Hessische Stiftung Friedens und Konfliktforschung (HSFK), Peace Research Institute Frankfurt (PRIF): Frankfurt, Germany, 2020.

4. Bluhm, R.; Gassebner, M.; Langlotz, S.; Schaudt, P. Fueling Conflict? (De)Escalation and Bilateral Aid. J. Appl. Econom. 2021, 36, 244-261. [CrossRef]

5. Collier, P.; Hoeffler, A. AID, Policy and Peace: Reducing the Risks of Civil Conflict. Def. Peace Econ. 2002, 13, 435-450. [CrossRef]

6. De Ree, J.; Nillesen, E. Aiding Violence or Peace? The Impact of Foreign Aid on the Risk of Civil Conflict in Sub-Saharan Africa. J. Dev. Econ. 2009, 88, 301-313. [CrossRef]

7. Klingebiel, S. The Impact of Development Co-Operation in Conflict Situations: German Experience in Six Countries. Evaluation 2001, 7, 63-78. [CrossRef]

8. Nunn, N.; Qian, N. US Food Aid and Civil Conflict. Am. Econ. Rev. 2014, 104, 1630-1666. [CrossRef]

9. Ofstad, A. Countries in Violent Conflict and Aid Strategies: The Case of Sri Lanka. World Dev. 2002, 30, 165-180. [CrossRef]

10. Savun, B.; Tirone, D.C. Exogenous Shocks, Foreign Aid, and Civil War. Int. Organ. 2012, 66, 363-393. [CrossRef]

11. Zürcher, C. What Do We (Not) Know About Development Aid and Violence? A Systematic Review. World Dev. 2017, 98, 506-522. [CrossRef]

12. Böhnke, J.R.; Zürcher, C. Aid, Minds and Hearts: The Impact of Aid in Conflict Zones. Confl. Manag. Peace Sci. 2013, 30, 411-432. [CrossRef] 
13. Crost, B.; Felter, J.; Johnston, P. Aid Under Fire: Development Projects and Civil Conflict. Am. Econ. Rev. 2014, 104, 1833-1856. [CrossRef]

14. Wencker, T.; Verspohl, I. German Development Cooperation in Fragile Contexts; German Institute for Development Evaluation (DEval): Bonn, Germany, 2019.

15. Wood, R.M.; Sullivan, C. Doing Harm by Doing Good? The Negative Externalities of Humanitarian Aid Provision during Civil Conflict. J. Polit. 2015, 77, 736-748. [CrossRef]

16. Zürcher, C. The Folly of "Aid for Stabilisation". Third World Q. 2019, 40, 839-854. [CrossRef]

17. Gehring, K.; Kaplan, L.C.; Wong, M. China and the World Bank: How Contrasting Development Approaches Affect State Stability; Aid Data Working Paper; AidData at William \& Mary: Williamsburg, VA, USA, 2019.

18. Van Weezel, S. A Spatial Analysis of the Effect of Foreign Aid in Conflict Areas; AidData Working Paper; AidData at William \& Mary: Williamsburg, VA, USA, 2015.

19. Child, T.B. Conflict and Counterinsurgency Aid: Drawing Sectoral Distinctions. J. Dev. Econ. 2019, 141, 102245. [CrossRef]

20. Wood, R.M.; Molfino, E. Aiding Victims, Abetting Violence: The Influence of Humanitarian Aid on Violence Patterns During Civil Conflict. J. Glob. Secur. Stud. 2016, 1, 186-203. [CrossRef]

21. Alesina, A.; Dollar, D. Who Gives Foreign Aid to Whom and Why? J. Econ. Growth 2000, 5, 33-63. [CrossRef]

22. Maizels, A.; Nissanke, M.K. Motivations for Aid to Developing Countries. World Dev. 1984, 12, 879-900. [CrossRef]

23. Balla, E.; Reinhardt, G.Y. Giving and Receiving Foreign Aid: Does Conflict Count? World Dev. 2008, 36, 2566-2585. [CrossRef]

24. Collier, P.; Dollar, D. Aid Allocation and Poverty Reduction. Eur. Econ. Rev. 2002, 46, 1475-1500. [CrossRef]

25. Canavire, G.; Nunnenkamp, P.; Thiele, R.; Triveño, L. Assessing the Allocation of Aid: Developmental Concerns and the Self-Interest of Donors. Indian Econ. J. 2006, 54, 26-51. [CrossRef]

26. Berthélemy, J.-C. Bilateral Donors' Interest vs. Recipients' Development Motives in Aid Allocation: Do All Donors Behave the Same? Rev. Dev. Econ. 2006, 10, 179-194. [CrossRef]

27. Burnside, C.; Dollar, D. Aid, Policies, and Growth. Am. Econ. Rev. 2000, 90, 847-868. [CrossRef]

28. Lis, P. Armed Conflict, Terrorism, and the Allocation of Foreign Aid. Econ. Peace Secur. J. 2013, 8. [CrossRef]

29. Öhler, H.; Nunnenkamp, P. Needs-Based Targeting or Favoritism? The Regional Allocation of Multilateral Aid within Recipient Countries: Needs-Based Targeting or Favoritism? Kyklos 2014, 67, 420-446. [CrossRef]

30. Jablonski, R.S. How Aid Targets Votes: The Impact of Electoral Incentives on Foreign Aid Distribution. World Polit. 2014, 66, 293-330. [CrossRef]

31. Hodler, R.; Raschky, P.A. Regional Favoritism. Q. J. Econ. 2014, 129, 995-1033. [CrossRef]

32. Masaki, T. The Political Economy of Aid Allocation in Africa: Evidence from Zambia. Afr. Stud. Rev. 2018, 61, 55-82. [CrossRef]

33. Bezerra, P.; Braithwaite, A. Locating Foreign Aid Commitments in Response to Political Violence. Public Choice 2016, 169, 333-355. [CrossRef]

34. Isenman, P.; Ehrenpreis, D. Results of the OECD DAC/Development Centre Experts' Seminar on "Aid Effectiveness and Selectivity: Integrating Multiple Objectives into Aid Allocations". DAC J. 2003, 4, 7-25.

35. Dipendra, K.C. Which Aid Targets Poor at the Sub-National Level? World Dev. Perspect. 2020, 17, 100177. [CrossRef]

36. Francken, N.; Minten, B.; Swinnen, J.F.M. The Political Economy of Relief Aid Allocation: Evidence from Madagascar. World Dev. 2012, 40, 486-500. [CrossRef]

37. Ruttan, V.W. Integrated Rural Development Programmes: A Historical Perspective. World Dev. 1984, 12, 393-401. [CrossRef]

38. Dreher, A.; Gehring, K.; Klasen, S. Gesture Politics or Real Commitment? Gender Inequality and the Allocation of Aid. World Dev. 2015, 70, 464-480. [CrossRef]

39. Kleemann, L.; Nunnenkamp, P.; Thiele, R. Gender Inequality, Female Leadership and Aid Allocation: A Panel Analysis of Aid for Education. J. Int. Dev. 2016, 28, 376-395. [CrossRef]

40. Briggs, R.C. Does Foreign Aid Target the Poorest? Int. Organ. 2017, 71, 187-206. [CrossRef]

41. Kotsadam, A.; Østby, G.; Rustad, S.A.; Tollefsen, A.F.; Urdal, H. Development Aid and Infant Mortality. Micro-Level Evidence from Nigeria. World Dev. 2018, 105, 59-69. [CrossRef]

42. Rustad, S.; Hoelscher, K.; Østby, G.; Urdal, H. Does Development Aid Address Political Exclusion? A Disaggregated Study of the Location of Aid in Sub-Saharan Africa; AidData Working Paper; AidData at William \& Mary: Williamsburg, VA, USA, 2019.

43. Platteau, J.-P.; Gaspart, F. The Risk of Resource Misappropriation in Community-Driven Development. World Dev. 2003, 31, 1687-1703. [CrossRef]

44. Ibarra Melo, M.E. Peace in Colombia Is Also a Women's Issue. Multidiscip. J. Gend. Stud. 2016, 5, 887. [CrossRef]

45. Kreft, A.-K. Responding to Sexual Violence: Women's Mobilization in War. J. Peace Res. 2019, 56, 220-233. [CrossRef]

46. Sánchez, F.; Solimano, A.; Formisano, M. Conflict, Violence and Crime in Colombia. Underst. Civ. War 2005, 2, 119-159.

47. Brüntrup-Seidemann, S.; Gantner, V.; Heucher, A.; Wiborg, I. Förderung der Gleichberechtigung der Geschlechter in Post-KonfliktKontexten; Deutsches Evaluierungsinstitut der Entwicklungszusammenarbeit (DEval): Bonn, Germany, 2021.

48. Sierra, J.R.; González, J.C. Colombia y El Acuerdo de Paz Con Las FARC-EP: Entre La Paz Territorial Que No Llega y La Violencia Que No Cesa. Rev. Esp. Cienc. Política 2021, 55, 63-91.

49. Salas-Salazar, L. Armed Conflict and Territorial Configuration: Elements for the Consolidation of the Peace in Colombia. Bitacora Urbano Territ. 2016, 26, 45-57. [CrossRef] 
50. Saldarriaga, J.F.; Hua, Y. A Gravity Model Analysis of Forced Displacement in Colombia. Cities 2019, 95, 102407. [CrossRef]

51. HRW. World Report 2017; Human Rights Watch: New York, NY, USA, 2017; ISBN 978-1-60980-734-4.

52. Plümper, T.; Neumayer, E. The Unequal Burden of War: The Effect of Armed Conflict on the Gender Gap in Life Expectancy. Int. Organ. 2006, 60, 723-754. [CrossRef]

53. RUV. Registro Único de Víctimas (RUV). Available online: https://www.unidadvictimas.gov.co/es/registro-unico-de-victimas$\mathrm{ruv} / 37394$ (accessed on 21 July 2020).

54. Acosta, M.; Castañeda, A.; García, D.; Hernández, F.; Muelas, D.; Santamaria, A. The Colombian Transitional Process: Comparative Perspectives on Violence against Indigenous Women. Int. J. Transit. Justice 2018, 12, 108-125. [CrossRef]

55. Alzate, M.M. The Sexual and Reproductive Rights of Internally Displaced Women: The Embodiment of Colombia's Crisis. Disasters 2008, 32, 131-148. [CrossRef] [PubMed]

56. Wirtz, A.L.; Pham, K.; Glass, N.; Loochkartt, S.; Kidane, T.; Cuspoca, D.; Rubenstein, L.S.; Singh, S.; Vu, A. Gender-Based Violence in Conflict and Displacement: Qualitative Findings from Displaced Women in Colombia. Confl. Health 2014, 8, 10. [CrossRef] [PubMed]

57. Friedemann-Sanchez, G.; Lovaton, R. Intimate Partner Violence in Colombia: Who Is at Risk? Soc. Forces 2012, 91, 663-688. [CrossRef]

58. Sandvik, K.B.; Lemaitre, J. Internally Displaced Women as Knowledge Producers and Users in Humanitarian Action: The View from Colombia. Disasters 2013, 37, S36-S50. [CrossRef]

59. Tovar-Restrepo, M.; Irazábal, C. Indigenous Women and Violence in Colombia: Agency, Autonomy, and Territoriality. Lat. Am. Perspect. 2014, 41, 39-58. [CrossRef]

60. UNSC. United Nations Security Council Resolution 1325 (2000) on Women, Peace and Security. In Understanding the Implications, Fulfilling the Obligations; United Nations Security Council Resolution 1325; United Nations Security Council: New York, NY, USA, 2000.

61. OSAGI. Landmark Resolution on Women, Peace and Security; Office of the Special Adviser to the Secretary-General on Gender Issues and Advancement of Women: Geneva, Switzerland, 2021.

62. UN. Transforming Our World. The 2030 Agenda for Sustainable Development. 2015. Available online: https://sdgs.un.org/2030 agenda (accessed on 14 February 2022).

63. Arostegui, J. Gender, Conflict, and Peace-Building: How Conflict Can Catalyse Positive Change for Women. Gend. Dev. 2013, 21, 533-549. [CrossRef]

64. Piscopo, J.M.; Wylie, K.N. Gender, Race, and Political Representation in Latin America. In Oxford Research Encyclopedia of Politics; Oxford University Press: Oxford, UK, 2020; ISBN 978-0-19-022863-7.

65. Fajardo, E.; Romero, H.; Álvarez, M.; Vargas, J. Participation of Women in the Labor Market in Colombia: Challenges and Recent Trends. Rev. Espac. 2018, 39, 12-20.

66. BMZ. Gleichberechtigung Der Geschlechter in Der Deutschen Entwicklungspolitik: Übersektorales Konzept; Strategic Paper; Bundesministerium für wirtschaftliche Zusammenarbeit und Entwicklung: Bonn, Germany, 2014.

67. OECD. Stat Extracts Database. Creditor Reporting System; Organization for Economic Cooperation and Development: Paris, France, 2020.

68. BMZ. Hopes of Peace and Stability; Bundesministerium für wirtschaftliche Zusammenarbeit und Entwicklung: Bonn, Germany, 2021.

69. AidData. Colombia AIMS Geocoded Research Release Level 1 v.1.1.1; AidData at William \& Mary: Williamsburg, VA, USA, 2016.

70. AidData. Financing the SDGs in Colombia; AidData at William \& Mary: Williamsburg, VA, USA, 2017.

71. Högbladh, S. UCDP GED Codebook Version 19.1; Department of Peace and Conflict Research, Uppsala University: Uppsala, Sweden, 2019

72. Sundberg, R.; Melander, E. Introducing the UCDP Georeferenced Event Dataset. J. Peace Res. 2013, 50, 523-532. [CrossRef]

73. MPC. Integrated Public Use Microdata Series, International: Version 7.2 [Dataset]; Minnesota Population Center: Minneapolis, MN, USA, 2019.

74. DNP-DDDR. Resultados de Desempeño Integral de Los Departamentos y Municipios de La Vigencia 2017; Desempeño Municipal; Departamento Nacional de Planeación (DNP), Dirección de Descentralización y Desarrollo Regional (DDDR), Gobierno de Colombia: Bogotá, Colombia, 2017.

75. Goodman, S.; BenYishay, A.; Lv, Z.; Runfola, D. GeoQuery: Integrating HPC Systems and Public Web-Based Geospatial Data Tools. Comput. Geosci. 2019, 122, 103-112. [CrossRef]

76. NOAA. Visible Infrared Imaging Radiometer Suite (VIIRS) Day/Night Band (DNB) [Dataset]; Earth Observation Group, NOAA National Centers for Environmental Information (NCEI): Asheville, NC, USA, 2020.

77. AidData. REE Geocoding Methodology; Version 2.0.2; AidData at William \& Mary: Williamsburg, VA, USA, 2017.

78. Ziaja, S.; Grävingholt, J.; Kreibaum, M. Constellations of Fragility: An Empirical Typology of States. Stud. Comp. Int. Dev. 2019, 54, 299-321. [CrossRef]

79. Hay, C.; Lister, M. Introduction: Theories of the State. In The State: Theories and Issues; Hay, C., Lister, M., Marsh, D., Eds.; Macmillan Education: London, UK, 2006; pp. 1-20; ISBN 978-0-230-80227-8. 
80. Grown, C.; Addison, T.; Tarp, F. Aid for Gender Equality and Development: Lessons and Challenges. J. Int. Dev. 2016, 28, 311-319. [CrossRef]

81. Kabeer, N. Gender Equality and Women's Empowerment: A Critical Analysis of the Third Millennium Development Goal 1. Gend. Dev. 2005, 13, 13-24. [CrossRef]

82. Sen, G.; Mukherjee, A. No Empowerment without Rights, No Rights without Politics: Gender-Equality, MDGs and the Post-2015 Development Agenda. J. Hum. Dev. Capab. 2014, 15, 188-202. [CrossRef]

83. Bali Swain, R.; Garikipati, S.; Wallentin, F.Y. Does Foreign Aid Improve Gender Performance in Recipient Countries? J. Int. Dev. 2020, 32, 1171-1193. [CrossRef]

84. Arias, E.; Palloni, A. Prevalence and Patterns of Female Headed Households in Latin America: 1970-1990. J. Comp. Fam. Stud. 1999, 30, 257-279. [CrossRef]

85. Bradshaw, S.; Chant, S.; Linneker, B. Challenges and Changes in Gendered Poverty: The Feminization, De-Feminization, and Re-Feminization of Poverty in Latin America. Fem. Econ. 2019, 25, 119-144. [CrossRef]

86. DANE. UN Women Boletín Estadístico: Empoderamiento Económico de Las Mujeres En Colombia; Departamento Administrativo Nacional de Estadística \& UN Women: Bogota, Colombia, 2019.

87. Castro, M.G. Similarities and Differences: Female-Headed Households in Brazil and Colombia. In Where Did All the Men Go? Routledge: London, UK, 2019; pp. 131-169.

88. Ibanez, A.M.; Moya, A. Vulnerability of Victims of Civil Conflicts: Empirical Evidence for the Displaced Population in Colombia. World Dev. 2010, 38, 647-663. [CrossRef]

89. Meertens, D. Forced Displacement and Women's Security in Colombia. Disasters 2010, 34, S147-S164. [CrossRef]

90. Angulo, R.; Díaz, Y.; Pardo, R. The Colombian Multidimensional Poverty Index: Measuring Poverty in a Public Policy Context. Soc. Indic. Res. 2016, 127, 1-38. [CrossRef]

91. Bernal, S.R. The Informal Labor Market in Colombia: Identification and Characterization. Rev. Desarro. Soc. 2009, 145-208. [CrossRef]

92. ILO. Women and Men in the Informal Economy: A Statistical Picture, 3rd ed.; International Labour Office: Geneva, Switzerland, 2018.

93. UNESCO. Literacy Rate; United Nations Educational, Scientific and Cultural Organization: Geneva, Switzerland, 2021.

94. Dickson, J.R.; Hughes, B.B.; Irfan, M.T. Advancing Global Education; Routledge: London, UK, 2015.

95. Amarante, V.; Rossel, C. Unfolding Patterns of Unpaid Household Work in Latin America. Fem. Econ. 2018, 24, 1-34. [CrossRef]

96. OECD. Education at a Glance 2019: OECD Indicators; Education at a Glance; OECD Publishing: Paris, France, 2019; ISBN 978-92-64-80398-5.

97. Grant, M.J.; Behrman, J.R. Gender Gaps in Educational Attainment in Less Developed Countries. Popul. Dev. Rev. 2010, 36, 71-89. [CrossRef]

98. Gerardino, M.P. The Effect of Violence on the Educational Gender Gap; Universitat Pompeu Fabra: Barcelona, Spain, 2014.

99. Buhaug, H.; Lujala, P. Accounting for Scale: Measuring Geography in Quantitative Studies of Civil War. Polit. Geogr. 2005, 24, 399-418. [CrossRef]

100. Briggs, R.C. Poor Targeting: A Gridded Spatial Analysis of the Degree to Which Aid Reaches the Poor in Africa. World Dev. 2018, 103, 133-148. [CrossRef]

101. Guillon, M.; Mathonnat, J. What Can We Learn on Chinese Aid Allocation Motivations from Available Data? A Sectorial Analysis of Chinese Aid to African Countries. China Econ. Rev. 2019, 60, 1-21. [CrossRef]

102. Ramírez, O.A.; Shultz, S.D. Poisson Count Models to Explain the Adoption of Agricultural and Natural Resource Management Technologies by Small Farmers in Central American Countries. J. Agric. Appl. Econ. 2000, 32, 21-33. [CrossRef]

103. Harrison, X.A. Using Observation-Level Random Effects to Model Overdispersion in Count Data in Ecology and Evolution. PeerJ 2014, 2, 1-17. [CrossRef]

104. Zuur, A.F.; Leno, E.N.; Walker, N.; Saveliev, A.A.; Smith, G.M. Mixed Effects Models and Extensions in Ecology with R; Statistics for Biology and Health; Springer: New York, NY, USA, 2009; ISBN 978-0-387-87458-6.

105. Allison, P.D. Fixed Effects Regression Models; Quantitative Applications in the Social Sciences; SAGE: Washington, DC, USA, 2009; ISBN 978-0-7619-2497-5.

106. Cameron, A.C.; Trivedi, P.K. Regression Analysis of Count Data, 2nd ed.; Econometric Society Monographs; Cambridge University Press: Cambridge, UK, 2013; ISBN 978-1-107-66727-3.

107. Huber, P.J. The Behavior of Maximum Likelihood Estimates under Nonstandard Conditions. In Proceedings of the Fifth Berkeley Symposium on Mathematical Statistics and Probability; Le Cam, L.M., Neyman, J., Eds.; University of California Press: Berkeley, CA, USA, 1967; pp. 221-223.

108. White, H. A Heteroskedasticity-Consistent Covariance Matrix Estimator and a Direct Test for Heteroskedasticity. Econometrica 1980, 48, 817-838. [CrossRef]

109. Pampel, F.C. Logistic Regression: A Primer; Sage University Papers Quantitative Applications in the Social Sciences; SAGE: Thousand Oaks, CA, USA, 2008; ISBN 978-0-7619-2010-6.

110. Collier, P.; Hoeffler, A.; Söderbom, M. Post-Conflict Risks. J. Peace Res. 2008, 45, 461-478. [CrossRef]

111. Hair, J.F.; Anderson, R.; Tatham, R.; Black, W.C. Multivariate Data Analysis, 3rd ed.; MacMillan: New York, NY, USA, 1995. 
112. Sturman, M.C. Multiple Approaches to Analyzing Count Data in Studies of Individual Differences: The Propensity for Type I Errors, Illustrated with the Case of Absenteeism Prediction. Educ. Psychol. Meas. 1999, 59, 414-430. [CrossRef]

113. Coxe, S.; West, S.G.; Aiken, L.S. The Analysis of Count Data: A Gentle Introduction to Poisson Regression and Its Alternatives. J. Pers. Assess. 2009, 91, 121-136. [CrossRef] [PubMed]

114. Oster, E. Unobservable Selection and Coefficient Stability: Theory and Evidence. J. Bus. Econ. Stat. 2019, 37, 187-204. [CrossRef]

115. Nawrotzki, R.J. The Politics of Environmental Concern: A Cross-National Analysis. Organ. Environ. 2012, 25, 286-307. [CrossRef]

116. Ruiter, S.; De Graaf, N.D. National Context, Religiosity, and Volunteering: Results from 53 Countries. Am. Sociol. Rev. 2006, 71, 191-210. [CrossRef]

117. Firchow, P. Must Our Communities Bleed to Receive Social Services? Development Projects and Collective Reparations Schemes in Colombia. J. Peacebuilding Dev. 2013, 8, 50-63. [CrossRef]

118. Kaplan, O.; Nussio, E. Community Counts: The Social Reintegration of Ex-Combatants in Colombia. Confl. Manag. Peace Sci. 2018, 35, 132-153. [CrossRef]

119. Theidon, K. Transitional Subjects: The Disarmament, Demobilization and Reintegration of Former Combatants in Colombia. Int. J. Transit. Justice 2007, 1, 66-90. [CrossRef]

120. Carrillo, A.C. Internal Displacement in Colombia: Humanitarian, Economic and Social Consequences in Urban Settings and Current Challenges. Int. Rev. Red Cross 2009, 91, 527-546. [CrossRef]

121. GIZ. Promising Practices: On the Human Rights-Based Approach in German Development Cooperation Peace-Building: Support to Survivors of Gender-Based Violence and to Indigenous People in Colombia; Deutsche Gesellschaft für International Zusammenarbeit (GIZ): Bonn, Germany; German Institute for Human Rights: Eschborn, Germany, 2016.

122. Greenberg, M.E.; Zuckerman, E. The Gender Dimensions of Post-Conflict Reconstruction: The Challenges in Development Aid. In Making Peace Work; Addison, T., Brück, T., Eds.; Palgrave Macmillan UK: London, UK, 2009; pp. 101-135; ISBN 978-1-349-30804-0.

123. Hoveskog, M.; Preciado, D.J.S.; Ortiz, H.B.P. 21 Days of Change: Addressing the Post-War Consequences on Women's Well-Being in Colombia; SAGE Publications; SAGE Business Cases Originals: Thousand Oaks, CA, USA, 2020.

124. Alther, G. Colombian Peace Communities: The Role of NGOs in Supporting Resistance to Violence and Oppression. Dev. Pract. 2006, 16, 278-291. [CrossRef]

125. Tarnaala, E. Legacies of Violence and the Unfinished Past: Women in Post-Demobilization Colombia and Guatemala. Peacebuilding 2019, 7, 103-117. [CrossRef]

126. Gender Association. The Other Side of the Mirror; Gender Associations International Consulting Group: Berlin/Heidelberg, Germany, 2020.

127. Domingo, P.; Rocha Menocal, A.; Hinestroza, V. Progress despite Adversity: Women's Empowerment and Conflict in Colombia; Overseas Development Institute (ODI): London, UK, 2015.

128. Lemaitre, J.; Sandvik, K.B. Shifting Frames, Vanishing Resources, and Dangerous Political Opportunities: Legal Mobilization among Displaced Women in Colombia. Law Soc. Rev. 2015, 49, 5-38. [CrossRef]

129. Lemaitre, J. Transitional Justice and the Challenges of a Feminist Peace. Int. J. Const. Law 2020, 18, 455-460. [CrossRef]

130. Céspedes-Báez, L.M.; Jaramillo Ruiz, F. ‘Peace without Women Does Not Go!’Women's Struggle for Inclusion in Colombia's Peace Process with the FARC. Colomb. Int. 2018, 83-109. [CrossRef]

131. Restrepo, E.M. Leaders against All Odds: Women Victims of Conflict in Colombia. Palgrave Commun. 2016, 2, 16014. [CrossRef]

132. Mayala, B.K.; Dontamsetti, T.; Croft, T.N. Interpolation of DHS Survey Data at Subnational Administrative Level 2; DHS Spatial Analysis Reports No. 17; ICF International: Rockville, MD, USA, 2019.

133. Franco, S.; Suarez, C.M.; Naranjo, C.B.; Báez, L.C.; Rozo, P. The Effects of the Armed Conflict on the Life and Health in Colombia. Ciênc. Saúde Coletiva 2006, 11, 349-361. [CrossRef]

134. Handrahan, L. Conflict, Gender, Ethnicity and Post-Conflict Reconstruction. Secur. Dialogue 2004, 35, 429-445. [CrossRef]

135. Meertens, D.; Stoller, R. Facing Destruction, Rebuilding Life: Gender and the Internally Displaced in Colombia. Lat. Am. Perspect. 2001, 28, 132-148. [CrossRef]

136. Osorio Pérez, F.E. Forced Displacement among Rural Women in Colombia. Lat. Am. Perspect. 2008, 35, 29-40. [CrossRef]

137. Moser, C.O.N.; Clark, F.C. (Eds.) Victims, Perpetrators or Actors?: Gender, Armed Conflict and Political Violence; Palgrave Macmillan: London, UK, 2001.

138. Dollar, D.; Levin, V. The Increasing Selectivity of Foreign Aid, 1984-2003. World Dev. 2006, 34, 2034-2046. [CrossRef]

139. Hoeffler, A.; Outram, V. Need, Merit, or Self-Interest-What Determines the Allocation of Aid? Rev. Dev. Econ. 2011, 15, 237-250. [CrossRef]

140. Betzold, C.; Weiler, F. Allocation of Aid for Adaptation to Climate Change: Do Vulnerable Countries Receive More Support? Int. Environ. Agreem. Polit. Law Econ. 2017, 17, 17-36. [CrossRef]

141. Weiler, F.; Klöck, C.; Dornan, M. Vulnerability, Good Governance, or Donor Interests? The Allocation of Aid for Climate Change Adaptation. World Dev. 2018, 104, 65-77. [CrossRef]

142. Raleigh, C. The Search for Safety: The Effects of Conflict, Poverty and Ecological Influences on Migration in the Developing World. Glob. Environ. Change 2011, 21, S82-S93. [CrossRef] 
143. Wisner, B. Interactions between Conflict and Natural Hazards: Swords, Ploughshares, Earthquakes, Floods and Storms. In Facing Global Environmental Change: Environmental, Human, Energy, Food, Health and Water Security Concepts; Brauch, H.G., Spring, Ú.O., Grin, J., Mesjasz, C., Kameri-Mbote, P., Behera, N.C., Chourou, B., Krummenacher, H., Eds.; Hexagon Series on Human and Environmental Security and Peace Book Series; Springer: Berlin/Heidelberg, Germany, 2009; pp. 245-256; ISBN 978-3-540-68488-6.

144. Willmott, C.J.; Matsuura, K. Terrestrial Air Temperature and Precipitation: Monthly and Annual Time Series (1950-1999); University of Delaware: Newark, NJ, USA, 2001.

145. Felbab-Brown, V. The Coca Connection: Conflict and Drugs in Colombia and Peru. J. Confl. Stud. 2005, 25, 104-128.

146. Angrist, J.; Kugler, A. Rural Windfall or a New Resource Curse? Coca, Income, and Civil Conflict in Colombia; National Bureau of Economic Research: Cambridge, MA, USA, 2005; p. w11219.

147. Mejia, D.; Restrepo, P. Bushes and Bullets: Illegal Cocaine Markets and Violence in Colombia. SSRN Electron. J. 2013. [CrossRef]

148. Parada-Hernández, M.M.; Marín-Jaramillo, M. Cocalero Women and Peace Policies in Colombia. Int. J. Drug Policy 2021, 89, 103157. [CrossRef]

149. Brombacher, D.; Westerbarkei, J. From Alternative Development to Sustainable Development: The Role of Development within the Global Drug Control Regime. J. Illicit Econ. Dev. 2019, 1, 89-98. [CrossRef]

150. Ceron, C.A.A.; De los Rios-Carmenado, I.; Martín Fernández, S. Illicit Crops Substitution and Rural Prosperity in Armed Conflict Areas: A Conceptual Proposal Based on the Working with People Model in Colombia. Land Use Policy 2018, 72, 201-214. [CrossRef]

151. Thacker, S.; Adshead, D.; Fay, M.; Hallegatte, S.; Harvey, M.; Meller, H.; O’Regan, N.; Rozenberg, J.; Watkins, G.; Hall, J.W. Infrastructure for Sustainable Development. Nat. Sustain. 2019, 2, 324-331. [CrossRef]

152. CIESIN. ITOS Global Roads Open Access Data Set, Version 1 (GROADSv1); NASA Socioeconomic Data and Applications Center (SEDAC): Palisades, NY, USA, 2013.

153. Bennett, M.; Smith, L. Advances in Using Multitemporal Night-Time Lights Satellite Imagery to Detect, Estimate, and Monitor Socioeconomic Dynamics. Remote Sens. Environ. 2017, 192, 176-197. [CrossRef]

154. Doll, C.N.H.; Muller, J.-P.; Elvidge, C.D. Night-Time Imagery as a Tool for Global Mapping of Socioeconomic Parameters and Greenhouse Gas Emissions. AMBIO J. Hum. Environ. 2000, 29, 157-162. [CrossRef]

155. Ebener, S.; Murray, C.; Tandon, A.; Elvidge, C.C. From Wealth to Health: Modelling the Distribution of Income per Capita at the Sub-National Level Using Night-Time Light Imagery. Int. J. Health Geogr. 2005, 4, 5. [CrossRef]

156. Henderson, J.V.; Storeygard, A.; Weil, D.N. Measuring Economic Growth from Outer Space. Am. Econ. Rev. 2012, 102, 994-1028. [CrossRef]

157. Sutton, P.C.; Costanza, R. Global Estimates of Market and Non-Market Values Derived from Nighttime Satellite Imagery, Land Cover, and Ecosystem Service Valuation. Ecol. Econ. 2002, 41, 509-527. [CrossRef]

158. Younas, J. Motivation for Bilateral Aid Allocation: Altruism or Trade Benefits. Eur. J. Polit. Econ. 2008, 24, 661-674. [CrossRef]

159. Mberu, B.U. Internal Migration and Household Living Conditions in Ethiopia. Demogr. Res. 2006, 14, 509-540. [CrossRef]

160. Nawrotzki, R.J.; Riosmena, F.; Hunter, L.M. Do Rainfall Deficits Predict U.S.-Bound Migration from Rural Mexico? Evidence from the Mexican Census. Popul. Res. Policy Rev. 2013, 32, 129-158. [CrossRef]

161. Shultz, J.M.; Garfin, D.R.; Espinel, Z.; Araya, R.; Oquendo, M.A.; Wainberg, M.L.; Chaskel, R.; Gaviria, S.L.; Ordóñez, A.E.; Espinola, M.; et al. Internally Displaced "Victims of Armed Conflict" in Colombia: The Trajectory and Trauma Signature of Forced Migration. Curr. Psychiatry Rep. 2014, 16, 475. [CrossRef]

162. Fadnes, E.; Horst, C. Responses to Internal Displacement in Columbia: Guided by What Principles? Refuge 2009, 26, 111-120. [CrossRef]

163. Fagen, P.W.; Juan, A.F.; Stepputat, F.; Lopez, R.V. Protracted Displacement in Colombia: National and International Responses. In Catching Fire: Containing Forced Migration in a Volatile World; Lexington Lanham: Oxford, UK, 2006; pp. 73-117; ISBN 978-0-7391-1244-1.

164. Gottwald, M. Protecting Colombian Refugees in the Andean Region: The Fight against Invisibility. Int. J. Refug. Law 2004, 16, 517-546. [CrossRef]

165. Calderón, V.; Gafaro, M.; Ibáñez, A.M. Forced Migration, Female Labor Force Participation, and Intra-Household Bargaining: Does Conflict Empower Women? Doc. CEDE 2011, 2011, 1-46. [CrossRef]

166. Lozano-Gracia, N.; Piras, G.; Ibáñez, A.M.; Hewings, G.J.D. The Journey to Safety: Conflict-Driven Migration Flows in Colombia. Int. Reg. Sci. Rev. 2010, 33, 157-180. [CrossRef]

167. Berents, H. Children, Violence, and Social Exclusion: Negotiation of Everyday Insecurity in a Colombian Barrio. Crit. Stud. Secur. 2015, 3, 90-104. [CrossRef]

168. Gómez-Restrepo, C.; Cruz-Ramírez, V.; Medina-Rico, M.; Rincón, C.J. Mental Health in Displaced Children by Armed ConflictNational Mental Health Survey Colombia 2015. Actas Esp. Psiquiatr. 2018, 46, 51-57.

169. Hernández, P.; Romero, A. Adolescent Girls in Colombia's Guerrilla: An Exploration into Gender and Trauma Dynamics. J. Prev. Interv. Community 2003, 26, 21-38. [CrossRef] 
170. Nagle, L.E. How Conflict and Displacement Fuel Human Trafficking and Abuse of Vulnerable Groups. The Case of Colombia and Opportunities for Real Action and Innovative Solutions. Gron. J. Int. Law 2013, 1, 1. [CrossRef]

171. Cook, P. Strengthening Colombian Indicators for Protection in Early Childhood. Int. J. Child. Rights 2015, 23, 638-660. [CrossRef]

172. Cook, P.; Mack, E.; Manrique, M. Protecting Young Children from Violence in Colombia: Linking Caregiver Empathy with Community Child Rights Indicators as a Pathway for Peace in Medellin's Comuna 13. Peace Confl. J. Peace Psychol. 2017, $23,38-45$. [CrossRef] 